OPEN ACCESS

Edited by:

Xuelei Ma,

Sichuan University, China

Reviewed by:

Qi Zhao,

University of Macau, China Vincenzo Barnaba,

Sapienza University of Rome, Italy

Peng Xiao,

Shandong University, China

*Correspondence:

Feng Wang

wfeng@bit.edu.cn

Specialty section:

This article was submitted to

Cancer Immunity

and Immunotherapy,

a section of the journal

Frontiers in Immunology

Received: 04 November 2021 Accepted: 24 December 2021

Published: 14 January 2022

Citation:

Bai Z, Zhou Y, Ye Z, Xiong J, Lan H and Wang $F$ (2022) Tumor-Infiltrating

Lymphocytes in Colorectal Cancer:

The Fundamental Indication and Application on Immunotherapy.

Front. Immunol. 12:808964. doi: 10.3389/fimmu.2021.808964

\section{Tumor-Infiltrating Lymphocytes in Colorectal Cancer: The Fundamental Indication and Application on Immunotherapy}

\author{
Ziyi Bai ${ }^{1,2}$, Yao Zhou ${ }^{2}$, Zifan Ye ${ }^{1}$, Jialong Xiong ${ }^{1}$, Hongying Lan ${ }^{1}$ and Feng Wang ${ }^{1 *}$ \\ 1 Key Laboratory of Molecular Medicine and Biotherapy, School of Life Science, Beijing Institute of Technology, Beijing, \\ China, ${ }^{2}$ College of Bioinformatics Science and Technology, Harbin Medical University, Harbin, China
}

The clinical success of immunotherapy has revolutionized the treatment of cancer patients, bringing renewed attention to tumor-infiltrating lymphocytes (TILs) of various cancer types. Immune checkpoint blockade is effective in patients with mismatched repair defects and high microsatellite instability (dMMR-MSI-H) in metastatic colorectal cancer (CRC), leading the FDA to accelerate the approval of two programmed cell death 1 (PD-1) blocking antibodies, pembrolizumab and nivolumab, for treatment of dMMR-MSI-H cancers. In contrast, patients with proficient mismatch repair and low levels of microsatellite stability or microsatellite instability (pMMR-MSI-L/MSS) typically have low tumor-infiltrating lymphocytes and have shown unsatisfied responses to the immune checkpoint inhibitor. Different TILs environments reflect different responses to immunotherapy, highlighting the complexity of the underlying tumor-immune interaction. Profiling of TILs fundamental Indication would shed light on the mechanisms of cancerimmune evasion, thus providing opportunities for the development of novel therapeutic strategies. In this review, we summarize phenotypic diversities of TILs and their connections with prognosis in CRC and provide insights into the subsets-specific nature of TILs with different MSI status. We also discuss current clinical immunotherapy approaches based on TILs as well as promising directions for future expansion, and highlight existing clinical data supporting its use.

Keywords: tumor-infiltrating lymphocytes, tertiary lymphoid structures, microsatellite instability, immunotherapy, colorectal cancer

\section{INTRODUCTION}

Colorectal cancer (CRC) is a clinically common malignant tumor of the digestive system. According to Global Cancer Statistics of 2020, there are approximately 1.9 million newly diagnosed CRC patients and 935,000 CRC-related deaths, accounting for $10 \%$ of cancer cases and $9.4 \%$ of cancerrelated deaths worldwide (1). With deeper understanding of pathophysiology in colorectal cancer, 
the optimization of screening and the application of various treatments have effectively improved the 5-year survival rate (25). However, nearly $40 \%$ of patients with CRC end up relapsing, with recurrent or advanced metastasis. As a result, extensive researches are now being conducted to overcome the barriers to relapse and resistance, and to explore more effective targets.

In the past decade immunotherapy has achieved impressive success in eradicating malignant cells by harnessing the inherent mechanisms of the host immune system, transforming the therapeutic landscape for a variety of solid and hematological malignancies $(6,7)$. Among cancer immunotherapy strategies, immune checkpoint blockade has shown significant benefits. It is the most thoroughly studied class of immunotherapy to date, increasing the overall survival (OS) rates of patients with advanced melanoma, non-small-cell lung cancer (NSCLC), urothelial cancer (8-10). Immune checkpoint therapy rejuvenates $\mathrm{T}$ cells and allows the adaptive immune system to block immune escape caused by cascade activation of tumorspecific immune checkpoints, such as those controlled by programmed cell death protein (PD-1), programmed deathligand 1 (PD-L1) or cytotoxic $\mathrm{T}$ lymphocyte-associated protein 4 (CTLA-4) $(11,12)$. In the treatment of CRC, the PD-1 inhibitors pembrolizumab and nivolumab, which have been approved by the Food and Drug Administration (FDA), led a to durable response in patients with metastatic CRC that is mismatch-repair-deficient (dMMR) and microsatellite instability-high (MSI-H) (dMMR-MSI-H). Another inhibitor, ipilimumab, a fully-humanized monoclonal antibody that blocks CTLA-4, has also been approved by the FDA for combination with nivolumab in patients with dMMR-MSI-H CRC who have previously received chemotherapy.

According to The Cancer Genome Atlas Project's CRC study based on the array and sequencing technologies, CRC can be classified into two main types: $(1) \sim 16 \%$ hypermutated $(>12$ mutations per $10^{6}$ DNA bases) cancers with dMMR-MSI-H signature and (2) 84\% percent non-hypermutated $(<8.24$ mutations per $10^{6}$ DNA bases) with mismatch-repairproficient (pMMR) and have low levels of microsatellite instability (MSI-L) or microsatellite stable (MSS) (pMMR-MSIL/MSS) signature (13). Patients with pMMR-MSI-L/MSS have a worse prognosis than dMMR-MSI-H (14), and show unsatisfied responses to immune checkpoint inhibitors (ICIs) (15). In general, pMMR-MSI-L/MSS have low TMB, are often poorly infiltrated by TILs. Accumulating evidence has shown that tumor mutation burden and tumor-infiltrating-lymphocytes (TILs) correlate with ICIs response (16-18). Therefore, it is important to understand the relationship between genetic heterogeneity and the molecular level of TILs in CRC. In this review, we discuss the accumulating evidence about the fundamental feature of TILs and their prognostic value in the tumor micro-environment of CRC. We also review the clinical development of immune checkpoint inhibition in CRC and discuss the emerging clinical therapies for targeting TILs. Collectively, this work clarifies some aspects of TILs subsets discrepancy, which provides a scientific basis for a better understanding of the excessive interactions between immune cells and different genetic types of CRC.

\section{THE ROLE OF TILS IN ANTI- TUMOR IMMUNITY}

It is an increasing variety of investigations that support the importance of tumor immune infiltration, including lymphocytes [T cells, B cells, and natural killer (NK) cells], macrophages, dendritic cells, and neutrophils, revealing a wide patient-patient diversity $(19,20)$. For a long time in the past, colorectal cancer was regarded as immunogenic and difficult to be treated by immunotherapy. However, advances in the molecular characterization of tumor-associated antigens defined by $\mathrm{T}$ cells and methods for detecting antigen-specific $\mathrm{T}$ cell responses have changed the scientific community's view of this issue. Tumors with microsatellite instability, including CRC, accumulate inserts and deletions in DNA repeat sequences. About two-thirds of MSI tumors are sporadic, and one-third are hereditary (Lynch syndrome). The high mutational load and frequent frameshift mutations in MSI tumors lead to the production of many neoantigens recognized by the immune system, which can trigger the lymphocytic infiltrates. Although a portion of TILs is composed of immunosuppressant cells, these cells are specifically recruited and/or directed by the tumor to maintain the immune-privileged microenvironment. In contrast, some TILs reflect attempts by the immune system to counter tumor responses $(21,22)$.

It is noteworthy that several studies have identified a broad association among TILs, different histological characteristics of cancer, disease-free survival (DFS), cancer-specific survival (CS) and OS (23-26). A meta-analysis of 43 trials describing 21,015 CRC patients showed that high generalized tumor inflammatory infiltrate was associated with good OS (hazard ratio (HR), 0.65; 95\% confidence interval (95\% CI, 0.54-0.77), CS (HR, 0.58; 95\% CI, 0.46-0.73) and DFS (HR, 0.72; 95\% CI, 0.60-0.88) (27). Similarly, Rozek et al. found that high TILs $(\mathrm{HR}=0.76,95 \% \mathrm{CI}=$ 0.64 to $0.89, p<0.001$ ) was favorable prognostic factors for specific and OS in colorectal cancer through a multivariate analysis of 2,369 cases (28). However, the quantity and quality can significantly vary among CRC patients within CRC different MSI statue $(29,30)$. Next, we reviewed the association between TILs and survival in patients with CRC and the characteristics of major subsets of TILs in the literature with different MSI statue.

\section{CD8 $^{+}$CYTOTOXIC T CELLS}

$\mathrm{CD}^{+}$cytotoxic T lymphocytes (CTLs), a key component of the adaptive immune system, play an important role in immune defense against intracellular pathogens such as viruses, bacteria and tumors, which were regarded as a major driver of anti-tumor immunity $(31,32)$. The cytotoxicity process is carried out by several substances produced by $\mathrm{CD} 8^{+} \mathrm{T}$ cells, such as perforin, granzymes, granulysin, Fas ligand, and tumor necrosis factor $\alpha$ (TNF- $\alpha$ ) (33, 34). $\mathrm{CD}^{+}$CTLs mediates tumor rejection by recognizing tumor antigens and directly kill transformed cells. Effector $\mathrm{CD}^{+} \mathrm{T}$ cells in the tumor microenvironment generate Interleukin-2 (IL-2), IL-12 and Interferon- $\gamma($ IFN- $\gamma)$, which enhance $\mathrm{CD}^{+}$CTLs, leading to targeted tumor cell killing $(35,36)$. 
A recent study of most tumor-infiltrating immune cell subtypes revealed that $\mathrm{CD}^{+} \mathrm{T}$ cells had the greatest impact on patient survival (37). The role of $\mathrm{CD}^{+}$CTLs in prognosis was first analyzed in a large cohort of CRC more than 10 years ago $(24,32)$. Several studies have shown that elevated levels of CTLs in the tumor microenvironment are associated with antitumor effects and improved prognosis in various cancers (30, 38-40). Moreover, tumors from the patient cohorts categorized by a high or low density of immune infiltrate and presence or absence of metastases revealed that adequate immune infiltration with successful initiation and differentiation of $\mathrm{CD}^{+} \mathrm{T}$ cells is vital for successful suppression of metastasis development (41).

Microsatellite instability is a good predictor of the prognosis of colorectal cancer, and there is a close relationship between microsatellite instability and the abundance of tumor-infiltrating T-cells (Table 1). It is noteworthy that a study of automatic image analysis on 768 colorectal cancers has identified the density of $\mathrm{T}$ cell subsets in neoplastic epithelial areas was positively correlated with MSI-H (39). In particular, several immunohistochemistry studies have revealed an especially high infiltration of intraepithelial activated $\mathrm{CD}^{+} \mathrm{T}$ cells within microsatellite instability colorectal tumors (42-45). Dolcetti et al. using immunohistochemistry found that there were many cytotoxic infiltrating structures in tumor epithelial cells in MSI$\mathrm{H}$ patients. Moreover, granase $\mathrm{B}$ expression showed that these cytotoxic effects were more active in MSI-H tumors (5.3 \pm 4.5 vs $0.6 \pm 1.3, p<0.001)$ (46). Similarly, in another study evaluating the number of multiple immune cells in an in situ immune response of 490 patients with CRC, the total density of cytotoxic $\mathrm{T}$ cells was significantly higher in MSI samples than in MSS samples. Interestingly, due to the importance of accurate intratumoral localization of infiltrating immune cells, the study also measured the density within the tumor glands (intratumoral) or stroma. The group reported that MSI-H and MSS patients showed similar stromal $\mathrm{CD}^{+} \mathrm{T}$ cell densities and there was a significant increase in the density of $\mathrm{CD}^{+} \mathrm{T}$ cells within the tumor glands in MSI patients, in both the core and invasive margin of tumor (all $p<0.05$ ) (47). The same conclusion was also found in the study of Smedt et al., which identified high numbers of intra-epithelial $\mathrm{CD}^{+}$cells in MSI compared with MSS tumors $(48,49)$.

\section{T HELPER CELLS}

$\mathrm{CD}^{+}$helper $\mathrm{T}$ lymphocytes are mediators of cellular immunity and play a key role in the activation of other immune cells, such as $\mathrm{B}$ cells and cytotoxic $\mathrm{T}$ cells, modulating immune responses. $\mathrm{CD} 4{ }^{+}$helper $\mathrm{T}$ cells further differentiate into subsets with broad functions characterized by cytokine secretion and effector

TABLE 1 | The association of tumor infiltrating lymphocytes with microsatellite stability status in colorectal cancer.

\begin{tabular}{|c|c|c|c|c|}
\hline Author & Markers & $\begin{array}{c}\text { Sample size } \\
\text { (dMMR-MSI-H | } \\
\text { pMMR-MSI-L/ } \\
\text { MSS) }\end{array}$ & $\begin{array}{l}\text { Disease } \\
\text { stage }\end{array}$ & TILs feature \\
\hline Liu et al. (42) & $\begin{array}{l}\text { CD3, CD4, } \\
\text { CD8, CD56 }\end{array}$ & $167 / 163$ & I-IV & $\begin{array}{l}\text { dMMR group displayed higher CD8 cells }(p<0.01) . C^{2} 56^{+} \text {cells } C D 4^{+} \text {cell than } \mathrm{pMMR} \text { group (both } \\
\mathrm{p}<0.05 \text { ). }\end{array}$ \\
\hline $\begin{array}{l}\text { Flahec et al. } \\
(43)\end{array}$ & $\begin{array}{l}\text { CD3, CD4, } \\
\text { CD8, CD20, } \\
\text { CD68, FOXP3 }\end{array}$ & $35 / 34$ & I-IV & $\begin{array}{l}\text { dMMR tumors have more numerous intraepithelial }\left(\mathrm{CD}^{+}, \mathrm{CD}^{+}, \mathrm{FOXP}^{+}\right) \text {and stromal }\left(\mathrm{CD}^{+}\right) \\
\text {lymphocytes }\end{array}$ \\
\hline $\begin{array}{l}\text { Michael- } \\
\text { Robinson } \\
\text { et al. (44) }\end{array}$ & $\begin{array}{l}\text { CD3, CD8, } \\
\text { CD20 }\end{array}$ & $32 / 70$ & $\begin{array}{l}\text { Duke's } \\
\text { stage A- } \\
\text { D }\end{array}$ & $\begin{array}{l}\text { TILs were most abundant in MSI-H colorectal cancers in which } 23 / 32(72 \%) \text { scored as TILs positive. } \\
\text { Only 5/40 (12.5\%) MSS tumours and } 9 / 30(30 \%) \text { MSI-L cancers were TILs positive }(p<0.0001) \text {. }\end{array}$ \\
\hline $\begin{array}{l}\text { Phillips et al. } \\
\text { (45) }\end{array}$ & $\begin{array}{l}\text { CD3, CD4, } \\
\text { CD8 }\end{array}$ & 26/138 & NA & $\begin{array}{l}\text { MSI-H tumours showed significantly higher counts for } \mathrm{CD}^{+} \text {and } \mathrm{CD}^{+} \text {cells, but no differences were } \\
\text { found in CD4 counts. }\end{array}$ \\
\hline $\begin{array}{l}\text { Dolcetti et al. } \\
\text { (46) }\end{array}$ & $\begin{array}{l}\text { CD3, CD4, } \\
\text { CD8, CD56 }\end{array}$ & $18 / 37$ & $\begin{array}{l}\text { Duke's } \\
\text { A-D }\end{array}$ & $\begin{array}{l}\text { MSI cases carried significantly higher numbers of cytotoxic lymphocytes infiltrating within neoplastic } \\
\text { epithelial structures }(p<0.001)\end{array}$ \\
\hline $\begin{array}{l}\text { Mlecnik et al. } \\
(47)\end{array}$ & $\begin{array}{l}\text { CD8, CD20, } \\
\text { CD68, IL-17, } \\
\text { NKp46, } \\
\text { CD45RO }\end{array}$ & $186 / 114$ & I-IV & $\begin{array}{l}\text { A significant increase in cytotoxic T cell, B cell in tumors from MSI patients. MSI tumors had higher } \\
\text { densities of Th1. The MSS patients showed a significantly increased Th17 infiltration in the core and } \\
\text { invasive margin of tumor }(p<0.05)\end{array}$ \\
\hline $\begin{array}{l}\text { Smedt et al. } \\
(48)\end{array}$ & $\begin{array}{l}\text { CD3, CD4, } \\
\text { CD8, CD20, } \\
\text { CD68 }\end{array}$ & $29 / 27$ & I-IV & $\begin{array}{l}\text { An increased number of tumor-infiltrating cytotoxic T-lymphocytes }\left(\mathrm{CD} 8^{+}\right) \text {in MSI compared with MSS } \\
\text { tumors for both the tumor and peritumoral area. Quantification showed high numbers of intra-epithelial } \\
\mathrm{CD}^{+}, \mathrm{CD}^{+}, \mathrm{CD}^{+}, \mathrm{CD}^{+} \mathrm{O}^{+} \text {and } \mathrm{CD} 68^{+} \text {cells in MSI compared with MSS cancers (all } \mathrm{p}<=0.01 \text { ). }\end{array}$ \\
\hline $\begin{array}{l}\text { Nestarenkaite } \\
\text { et al. (49) }\end{array}$ & $\begin{array}{l}\text { CD8, CD20, } \\
\text { CD68 }\end{array}$ & $39 / 48$ & I-IV & $\begin{array}{l}\text { The } \mathrm{CD}^{+} \text {densities within tumor-stroma interface zone (IZ) and the intratumoral densities were higher } \\
\text { in MSI than in MSS tumors, whereas no differences in IZ and intratumoral CD20 cell densities were } \\
\text { observed comparing MSI and MSS tumors }\end{array}$ \\
\hline $\begin{array}{l}\text { Gouvello et al. } \\
(50)\end{array}$ & IL-17 & $10 / 11$ & I-IV & $\begin{array}{l}\text { Higher tumoral expression of Foxp3, IL-17, IL1-beta, IL-6 and TGF- } \beta \text { was associated with the MSS } \\
\text { phenotype, and the IL-17 T/TN (colon cancers/autologous normal colon mucosa) ratio was higher in } \\
\text { MSS tissues than in MSI-H tissues. }\end{array}$ \\
\hline $\begin{array}{l}\text { Michel et al. } \\
(51)\end{array}$ & $\begin{array}{l}\text { CD3, CD8, } \\
\text { FOXP3 }\end{array}$ & $37 / 33$ & $\begin{array}{l}\text { I-IV and } \\
\text { NA }\end{array}$ & $\begin{array}{l}\text { The elevated number of } \mathrm{CD}^{+} \text {lymphocytes found in } \mathrm{MSI}-\mathrm{H} \text { colorectal cancers is paralleled by an } \\
\text { enhanced infiltration with } \mathrm{CD}^{-} \mathrm{FOXP3}^{+} \text {cells }\end{array}$ \\
\hline
\end{tabular}

Th, Thelper; Treg, regulatory T cell; dMMR-MSI-H, mismatch-repair-deficient and microsatellite instability-high; pMMR-MSI-L/MSS, mismatch-repair-proficient and microsatellite-stable or have low levels of microsatellite instability; TILs, tumor infiltrating lymphocytes. 
function, including T helper 1 (Th1) cells, T helper 2 (Th2) cells, T helper 17 (Th17) cells, follicular helper T (Tfh) cells (reviewed in the later section) and regulatory $\mathrm{T}\left(\mathrm{T}_{\text {reg }}\right)$ cells.

The main effector function of Th1 cells lie in cell-mediated immunity and inflammation, including the activation of other immune cells such as macrophages, B cells and CD8 ${ }^{+}$CTLs lysis and other effector functions, which play an important role in clearing intracellular infection and assisting in killing tumor cells. Th1 cells and their derived cytokines (e.g., IFN- $\gamma$, TNF- $\alpha$, etc.) are strongly associated with good clinical outcomes in almost all cancer types $(21,25,41,52)$. In contrast to the effects of Th1, analysis of the effect of other $\mathrm{CD}^{+} \mathrm{T}$ cell subsets on clinical outcomes has yielded apparent contradictory results, remaining a matter of debate (Table 2). The prognostic effects of other T-helper cell populations (Th2, Th17, and $\mathrm{T}_{\text {reg }}$ cells) are also different across cancer types and stages. Th2 cells are usually associated with aggressive tumors, either by activating $B$ cells or producing the immunosuppressive cytokine IL-10 $(55,56,86)$. However, it is not a universal phenomenon. Multiple studies have shown that Th2 cells are associated with a good prognosis in Hodgkin's lymphoma (53) and breast cancer (54), but not in ovarian (55), gastric (57) and pancreatic cancer (56). There were also conflicting results regarding the role of Th17 cells, which are associated with poor prognosis [e.g., NSCLC (62) and hepatocellular carcinoma (63)] and improved survival [esophageal cancer (58), gastric cancer (59), ovarian cancer (60), cervical cancer (61)]. Th17 cells recruitment have been observed in a variety of malignancies in comparison with normal tissue. On the one hand, the potential of Th17 cells to transdifferentiate into a more immunosuppressive phenotype plays a role in tumor immune evasion. IL-17 (a cytokine produced by Th17 cells) cytokines are associated with increased vascular growth and thus increase tumor growth and metastasis in some models. On the other hand, Th17 cells recruit CTLs and dendritic cells to the tumor site to promote tumor clearance, similar to their ability to convert to a Th1 phenotype that secretes IFN- $\gamma$ under specific environmental factors (87). The role of Th17 cells in cancer progression appears to be highly dependent on the specific tumor microenvironment. Harnessing this plasticity to control them and improve anti-tumor responses may be a useful strategy for developing cancer immunotherapies. $\mathrm{T}_{\text {reg }}$ cells can inhibit antiautoimmune reactions, and there are different subsets (including thymic-derived $\mathrm{T}_{\text {reg}}$, peripheral $\mathrm{T}_{\text {reg, }}$ etc.). Similarly, the role of regulatory $\mathrm{T}$ cells has been a matter of debate for the past decade. Curiel et al. first demonstrated a correlation of intratumoral $\mathrm{T}_{\text {reg }}$ cells and poor survival in ovarian cancer (70). However, subsequent studies have reported inconsistent results, with $\mathrm{T}_{\text {reg }}$ cells having no effect on survival of anal squamous cell carcinoma (67), glioma (68), and glioblastoma (69), while showing positive effects on nasopharyngeal cancer (64), head and neck cancer (65), and hematological malignancies (66).

A growing number of studies have investigated the characteristics and prognostic potential of $\mathrm{T}$ helper cells in CRC adaptive immune response (Table 1). A study conducted by Liu and his colleagues showed that the $\mathrm{dMMR}$ group displayed much less $\mathrm{CD}_{5} 6^{+}$cell, $\mathrm{CD} 4^{+}$cell and MHC class I expression (all $p<0.05$ ) and higher CD8 expression $(p<0.01)$ than the pMMR group. Besides, in the dMMR group, low CD4 and CD56 expression were risk factors for low MHC class I expression in the univariate model (42). However, due to helper cells exhibiting a great diversity in phenotype, identification of the $\mathrm{T}$ helper cell subsets in tumors requires evaluation of some specific markers (including, but not limited to, mRNA and key cytokines) in addition to CD4 ${ }^{+}$. A study of 52 patients with CRC showed that IL-17 was co-stained with CD4 and CD68 by confocal microscopy analysis, which indicated IL-17 in colorectal cancer was expressed by macrophage and Th17. Compared to $\mathrm{T}_{\text {reg }}$ cells, other $\mathrm{T}$-helper cell subsets generally do not express distinct surface markers. As a result, several studies have assessed $\mathrm{T}$ helper cell abundance through gene expression profiles. In 2013, Bindea et al. performed microarray expression experiments in tumors from $105 \mathrm{CRC}$ patients showed that $\mathrm{CD} 8^{+}$and Th1 were associated with a good prognosis (DFS, HR < 1) (88), confirming previous reports from the same group (24). In this report, Th17 cells were also found to negatively influence the patient outcome (DFS, HR $>1, p<0.05$ ). In a large study of 125 frozen colorectal tumor specimens, immune-related genes indicated that patients with high expression of the Th17 cluster had a poor prognosis, whereas patients with high expression of the Th1 cluster had prolonged disease-free survival. In contrast, their results did not support the

TABLE 2 | The association of different types of TILs with tumor prognosis.

\begin{tabular}{|c|c|c|c|}
\hline $\begin{array}{l}\text { The types of } \\
\text { TILs }\end{array}$ & Reference & Prognosis & Tumor types \\
\hline $\mathrm{CD}^{+}$cell & $(30,37-40)$ & Good & Colorectal cancer etc. \\
\hline Th1 cell & $(21,25,41,52)$ & Good & Colorectal cancer etc. \\
\hline \multirow[t]{2}{*}{ Th2 cell } & $(53,54)$ & Good & Hodgkin lymphoma; Breast cancer \\
\hline & $(55-57)$ & Poor & Ovarian cancer; Pancreatic cancer; Gastric cancer \\
\hline \multirow[t]{2}{*}{ Th17 cell } & $(58-61)$ & Good & Esophageal squamous cell carcinoma; Gastric adenocarcinoma; Ovarian cancer; Squamous cervical cancer \\
\hline & $(62,63)$ & Poor & Non-small cell lung cancer; Hepatocellular carcinoma \\
\hline \multirow{3}{*}{$\mathrm{T}_{\text {reg }}$ cell } & $(64-66)$ & Good & Nasopharyngeal carcinoma; Head and neck cancer; Urinary bladder cancer \\
\hline & $(67-69)$ & None & Anal squamous cell carcinoma; Glioma; Glioblastomas \\
\hline & (70) & Poor & Ovarian carcinoma \\
\hline \multirow[t]{2}{*}{ NK cell } & $(71-76)$ & Good & Metastatic prostate cancer; Non-small cell lung cancer; Colorectal cancer; Mantle cell lymphoma \\
\hline & $(77,78)$ & Poor & Infiltrating ductal carcinoma of breast; Digestive cancer \\
\hline \multirow[t]{2}{*}{ B cell } & $(79-83)$ & Good & $\begin{array}{l}\text { Hepatocellular carcinoma with lymphocytic infiltration; Melanoma; Ovarian cancer; Non-small cell lung cancer; Stage IB } \\
\text { cervical squamous cell carcinoma }\end{array}$ \\
\hline & $(84,85)$ & Poor & Ovarian cancer; Breast cancer \\
\hline
\end{tabular}


primary role of Th2 cells in patient outcomes (52). Using single cell RNA-seq, Zhang et al. (89) found that among $\mathrm{CD}^{+} \mathrm{T}$ cells, most tumor-infiltrating Treg cells showed clonal exclusivity, while certain Treg cell clones were associated with the development of several $\mathrm{T}$ helper cells clones by single $\mathrm{T}$ cell transcriptome analysis (89). Notably, two IFNG ${ }^{+}$Th1-like cell clusters were also found in this study, only CXCL13 ${ }^{+}$BHLHE40 ${ }^{+}$Th1-like cells were preferentially enriched in patients with microsatellite-instable tumors.

$\mathrm{T}_{\text {reg }}$ cell is characterized by high expression of CD25 and the transcription factor fork head box protein P3 (FOXP3) $(64,90)$. Using quantitative reverse transcription-PCR (qRT-PCR) quantified for the expression of 15 markers of the immune response, Cui et al. found that higher expression of FOXP3, IL-17, IL1- $\beta$, IL-6 and TGF- $\beta$ were associated with the MSS phenotype (50). Moreover, a large study of 1,420 tumor samples found a significantly higher amount of $\mathrm{FOXP}^{+}$tumorinfiltrating $\mathrm{T}_{\text {reg }}$ in pMMR CRC samples (38). This study also observed an association between a high frequency of tumorinfiltrating $\mathrm{FOXP}^{+} \mathrm{T}_{\text {reg }}$ and improved survival in CRC patients, which is in accordance with the results reported by Gunnarsson et al. and Frey et al. $(91,92)$. In contrast, several studies have challenged the characterization of $\mathrm{T}_{\text {reg }}$ cells in CRC. In MSI-H CRC, Michel et al. found a significant increase in intraepithelial infiltration of $\mathrm{FOXP}^{+}$cells and in the ratio of intraepithelial to stromal infiltration. Similarly, in another study, CD45RO ${ }^{+}$and $\mathrm{FOXP}^{+}$cell densities were significantly correlated with MSI-H and the densities of $\mathrm{CD}^{+}, \mathrm{CD}^{2} 5 \mathrm{RO}^{+}$and $\mathrm{FOXP}^{+}$cells were significantly associated with patient survival in CRC (43). Given the diversity of $\mathrm{T}_{\text {reg }}$ populations observed in cancer, it is a great challenge of studying $\mathrm{T}$ helper cell subpopulations in the context of immunopathology.

\section{NK CELLS}

In recent years, the rapid and potent anti-tumor function of innate immunity, which even occurs at a very early stage of tumor progression, has attracted increasing attention. NK cells, as a subset of innate lymphoid cells, are able to control tumor growth as well as the initial stages of metastatic dissemination (93-95). Unlike other lymphocytes (including B cells, T cells, and natural killer T cells), NK cells do not express antigen-specific receptors such as B cell receptor/T cell receptor or CD3. Instead, NK cells possess cytotoxic abilities similar to $\mathrm{CD}^{+} \mathrm{T}$ cells, acting in an antigen-independent manner in the adaptive immunity. In addition to cytotoxic effects, NK cells have been reported to produce a large number of cytokines similar to T cells, including IL-2 (96), IL-7 (97), IL-15 (98), and IFN- $\gamma(99)$, to modulate adaptive immune responses and participate in other related pathways. Despite many similarities, compared with effector $\mathrm{T}$ cells, NK cells are more cytotoxic to tumors, possess lower immunogenicity and respond to target cells more quickly $(100,101)$. NK cells are highly heterogeneous, characterized by the abundance of surface receptors. According to surface CD56 expression, NK cells can be divided into 2 developmentally related, but functionally distinct, subsets: CD56 ${ }^{\text {bright }}$ and $\mathrm{CD} 56^{\mathrm{dim}}$. CD56 ${ }^{\mathrm{dim}} \mathrm{NK}$ cells are comprise $80 \%-$
95\% of peripheral blood NK cells, and are always also CD16 $6^{+}$ expressing high levels of KIR and LFA-1 and showing cell killing ability (102). However, CD56 ${ }^{\text {bright }} \mathrm{NK}$ cells are traditionally considered ineffective antitumor responders that instead function primarily in immunomodulation, which mainly secrete cytokines such as IFN- $\gamma$, TNF- $\beta$, and granulote-macrophage colonystimulating factor (GM-CSF) (103-105). Nevertheless, NK cells in various tissues (106-108), even in the same organ and tissue (109), have diverse features.

The specific role of NK cells, with the complexity of intrinsic signaling pathways, remains controversial in distinct cancer types (Table 2). Due to the complex and variable functional status, NK cells were shown to vary survival and therapeutic response in different types of cancer $(71,77,78,110-112)$. In CRC, NK cells have been consistently associated with increased survival in patients (72-76). It is noteworthy that CRC patients with dMMR-MSI-H and pMMR-MSI-L/MSS also seem to display different NK cell features (Table 1). The surface markers of NK cells vary greatly and it is difficult to accurately identify NK cell type by one or two simple molecules. However, in many studies, NK cells have been detected using CD56 as a phenotypic marker. Liu et al. assessed for the presence of NK cell infiltration in CRC tissues using the expression of CD56, and found that $\mathrm{CD}_{56}{ }^{+}$cells were reduced in the dMMR group $(p<$ $0.05)$ through immunohistochemical (42). In apparent contrast with these observations, Mlecnik et al. quantified the number of cells by detecting NKp46 and found no significant difference in NK cells between MSI and MSS patients (47). The mechanism of NK cells is complex and variable, and its actual role in the tumor microenvironment remains to be further clarified.

\section{B CELLS, TFH, AND TERTIARY LYMPHOID STRUCTURES}

\section{Tumor-Infiltrating B Lymphocytes}

$B$ cells, with a variety of immune functions, are recognized as the main effector cells of the humoral adaptive immune response. However, TIBs can be observed in various solid tumors, but their role in cancer remains controversial (Table 2). In HCC (79), melanoma (80), high-grade serous ovarian cancer (81), NSCLC (82) and stage IB cervical squamous cell carcinoma (83), increased B cell count is associated with improved clinical outcomes. However, in epithelial ovarian cancer (84) and breast cancer (85), B cell infiltration is correlated with poor prognosis. At present, studies on the prognostic potential of $B$ cells are limited. It is worth noting that most of the current studies quantify TIBs by CD20. A recently reported systematic review of TIBs into CRC showed that patients whose tumors were highly infiltrated by $\mathrm{CD}_{2} 0^{+} \mathrm{B}$ lymphocytes had a significantly improved DFS improvement DFS ( $\mathrm{HR}=0.45$, 95\% CI 0.28-0.73, $p=0.001$ ). Moreover, the author also found that $\mathrm{CD} 20^{+} \mathrm{B}$ lymphocytes were highly and positively associated with $\mathrm{CD}^{+} \mathrm{T}$ lymphocytes $(p<0.001)$ (113). Interestingly, a report demonstrated that an increase in the number of TIBs was associated with improved clinical outcomes for CRC (88). 
However, another report has given a complex interpretation of the roles of TIBs in CRC (49). It was observed that $\mathrm{CD}^{+}$and $\mathrm{CD} 20^{+}$immunogradient indicators, that reflect cell migration towards the tumor, were associated with improved patient survival, while the infiltrative tumor growth pattern was linked to worse patient outcomes. In addition, this study also found that high numbers of intra-epithelial $\mathrm{CD} 20^{+}$cells were observed in MSI tumors compared with MSS tumors and MSS colorectal tumors were characterized by elevated levels of intratumoral $\mathrm{CD} 20^{+}$.

\section{Tfh and TLSs}

Tfh cells, a T helper cells subset, are essential for the maturation and activation of $\mathrm{B}$ cells, which are characterized by the expression of CXCR5, an inducible T-cell co-stimulator. B cells, Tfh and related pathways also maintain the structure and function of the tertiary lymphoid structure. The interactions among Tfh cells, B cells and follicular dendritic cells are the basis of the adaptive immune response, which results in B cells differentiating into memory B cells and long-term surviving plasma cells. In addition, $\mathrm{B}$ cells can infiltrate into tumors and affect tumor progression through CXCL13 secreted by Tfh and follicular dendritic cells $(114,115)$. B cells, Tfh and related pathways also maintain the structure and function of the TLS. The current consensus is that the Tfh cell and B cell axis within tumor-associated TLSs contribute to the formation of anti-tumor immune structures (116). TLSs are transient ectopic lymphoid organs that share several structural and functional features with secondary lymphoid organs (117), and consist of B cell follicle and T-cellrich areas that are sites for the differentiation of $\mathrm{T}$ cells and $\mathrm{B}$ cells (118) (Figure 1). B cell follicle, composed of a core germinal centre containing mostly B cells, but also Tfh cells, follicular DCs and macrophages, surrounded by a ring of naive B cells; and a T-cellrich area, composed of clusters of T cells and mature DCs (119).

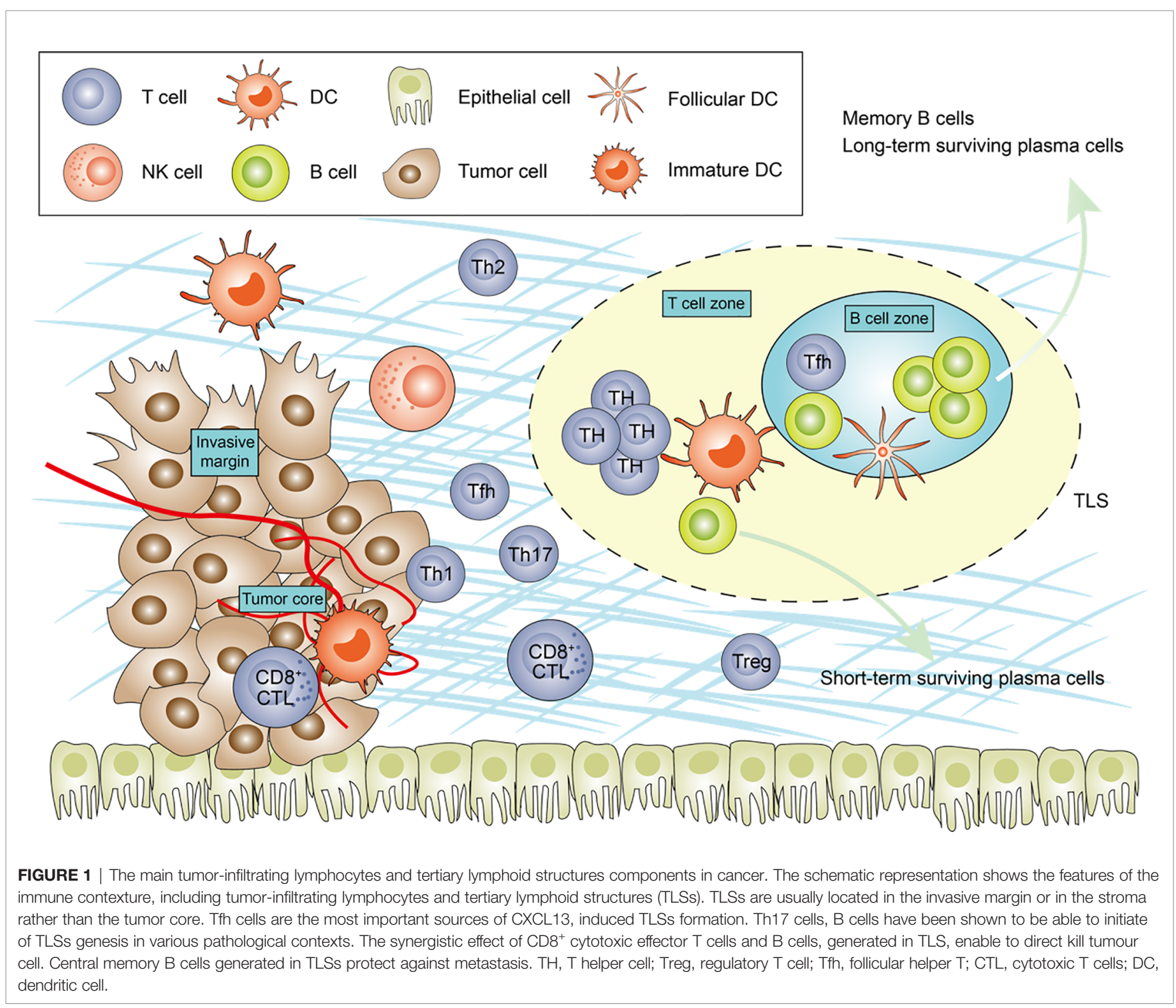


There is increasing evidence that TLS is an effective modulator of immune responses. TLSs are often [NSCLC (120), HER $2^{+}$breast cancer (121), melanoma (122)], but not always [HCC (123)], associated with favourable clinical outcomes in most types of cancer. In local and metastatic CRCs, TLSs are associated with improved survival and may represent activation of an adaptive immune response to malignant cells $(124,125)$. In a cohort study involving a consecutive series of 351 patients with stage II and III colorectal cancer, the TLSs density and infiltration of patients with stage II are correlated and coordinated to predict better patient outcomes (126). In addition, the murine model showed an active role of TLSs in the recruitment of lymphocytes to tumor areas. Moreover, certain heterogeneities exist among TLSs from different cancer types, locations and stages. Posch et al. performed a comprehensive molecular, tissue, laboratory, and clinical analysis of 109 patients with stage II/III CRC (127). TLSs were found to be formed in most tumors and were more prevalent in CRC with MSI$\mathrm{H}$ and/or BRAF mutations. In addition, the authors also found that TLSs maturation contained important prognostic information about the risk of disease recurrence. In a recent report examing the cellular composition and association with patients' prognosis in each TLSs, the authors reported that the densities of T helper cells and macrophages in TLSs were significantly higher in relapsed patients than in not-relapsed patients $(p=0.043$ and $p=0.0076)$ (128). Multivariate analysis also showed that a high proportion of $\mathrm{T}$ helper cells was the most significant independent risk factor for disease recurrence. In contrast, there is little data available regarding Tfh cells supporting anti-tumor responses in CRC. A high expression of Tfh and B cell genes was found strongly associated with a good prognosis in CRC according to Bindea et al. (88). The authors also found that Tfh and intrinsic cell density increased with tumor progression. Obviously, there are clearly interesting complexities to Tfh-associated biology in the context of cancer, and the available data show that much more needs to be learned.

\section{TILS AND IMMUNOTHERAPY}

\section{T-Cell-Based Immunotherapy}

In CRC, $\mathrm{T}$ cell infiltration into the tumor has been associated with good outcomes, and prevention of its exhaustion and apoptosis in tumors is the goal of immunotherapy, especially immune checkpoint inhibitors. ICIs target negative costimulation receptors or their ligands of TCR signals, such as CTLA4, PD-1 and PD-L1, to prevent tumor cells attenuate T-cell activation (129).

ICIs have shown very limited clinical activity in early studies of CRC treatment $(130,131)$. In 2015, a phase II study investigated the efficacy of pembrolizumab, a humanized IgG4 antibody directed against surface-expressed PD-1, in three separate cohorts of 41 patients with MSI-H and MSS CRC tumors, and MSI-H tumors from other sites (non-CRC). Results showed that the immune-related objective response rate was $40 \%$ (4 had a partial response and 5 had the stable disease) with dMMR-MSI-H patients, whereas there was no objective response in patients with MSS CRC.
The median progression-free survival (PFS) and OS were not yet reached in the dMMR-MSI-H cohort but were 2.2 months and 5.0 months, respectively, in the pMMR-MSI-L/MSS cohort (HR for disease progression $0.10(p<0.001)$; HR for death $0.22(p=0.05)$ (14). Similarly, another study of 53 patients treated with pembrolizumab showed the benefit of immune checkpoint blockade in dMMR-MSI-H tumors. The response rate was $50 \%$ (95\% CI 31-69\%), and the disease control rate was 89\% (25/28) in the 28 patients with dMMR-MSI-H tumors. At 24 months, PFS was $61 \%$, and OS was $66 \%$. None of the 18 patients with pMMR-MSI-L/ MSS CRC responded and the disease control rate was 16\% (4/25) (132). On May 23, 2017, FDA approved pembrolizumab based on the data from 149 patients ( $84 \%$ for colorectal cancer) for the treatment of adult and pediatric patients with unresectable or metastatic, dMMR-MSI-H solid tumors, regardless of tumor site or histology (133) (Figure 2). In addition to pembrolizumab, nivolumab, another PD-1 inhibitor, was tested in 74 patients with dMMR-MSI-H metastatic colorectal cancer (134). At a median follow-up duration of 12 months, the objective response rate was $31 \%(23 / 74)$, and in $69 \%(51 / 74)$ patients who had disease control for 12 weeks or longer were observed. In July 2017, FDA expedited approval of nivolumab for the second-line treatment of patients with dMMR-MSI-H CRC.

Compared with patients with dMMR-MSI-H CRC, immunotherapy alone has not shown a clinical benefit in patients with pMMR-MSI-L/MSS CRC. As a result, alternative approaches to immune modulation studies are ongoing. Tumor immune microenvironment, as a critical obstacle to the development of immunotherapy, has been studied with medications that have immunomodulatory properties. Indomethacin 2,3-double oxygenase 1 (IDO1) is an intracellular enzyme that can cause tryptophan depletion, has been reported to play multiple roles in cancer, including inhibiting $\mathrm{T}$ and NK cells, producing active Treg and myeloid-derived suppressor cells and promoting tumor angiogenesis (135). Kitsou et al. found that IDO1 was significantly overexpressed in CRC and exhibited anticancer activity (136). In murine intestinal adenomas cell-specific Stat1 deletion models, loss of $\mathrm{IDO}^{+}$Paneth cells had profound effects on the intratumoral immune cell composition. Moreover, the patient samples and TCGA expression data supported corresponding cells in human colorectal tumors, suggesting $\mathrm{IDO}^{+}$Paneth cells as a target for immunotherapy (137). Epacadostat, an IDO1 inhibitor, was planned to combinate with pimuzumab and azacytidine in the MSS CRC study. However, this study has been terminated at an early stage. Overall, the molecular of IDO1 inhibitor shows promising anti-tumor potential.

With the knowledge in CRC biology improved, another immunomodulatory strategy, the combination of MEK and PD-L1 inhibition, was developed. In many preclinical studies, inhibition of MEK, a downstream effector of the RAS-MAPK pathway, was found to induce PD-L1 upregulation (138). Preclinical data reported in 2016 showed that 4 of 23 patients with CRC had a partial response, in which three patients had confirmed pMMR-MSI-L (139). In addition, many clinical trials are also studying the combination of MEK inhibitor with antiPD1 antibody and other chemotherapeutic drugs. 

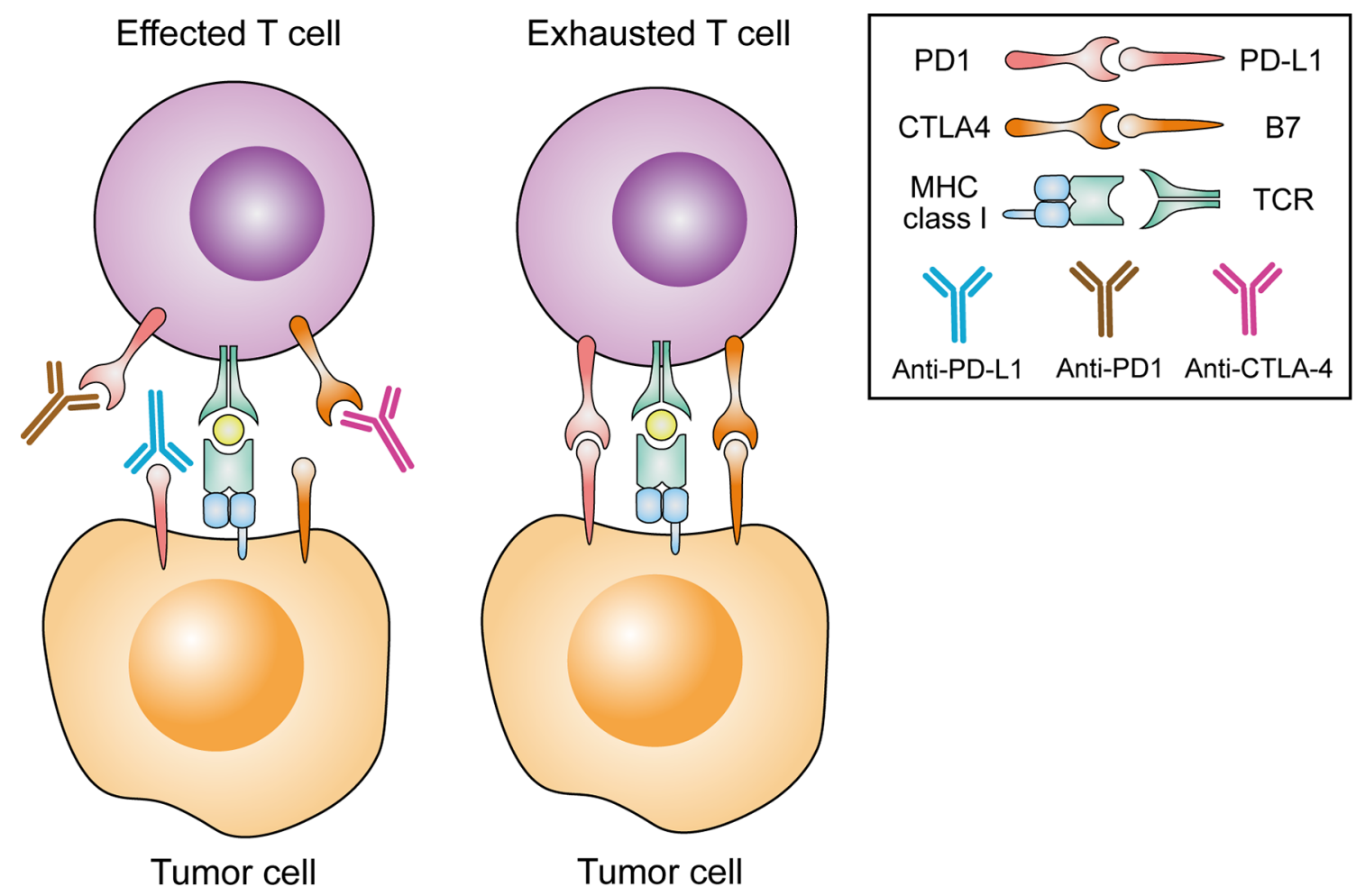

FIGURE 2 | Rationale for the current FDA-approved CRC immune checkpoint inhibitor strategies. TCR, T cell receptor; MHC, major histocompatibility complex; CTLA4, cytotoxic T lymphocyte antigen 4; PD1, programmed cell death 1; PD-L1, programmed cell death 1 ligand 1.

\section{The Emergence of Natural Killer Cells as a Target in Cancer Immunotherapy}

NK cells, as an important natural immune effector, are effector lymphocytes that control several types of tumors and microbial infections. In recent years, research on NK cell-related immunotherapy has been developing vigorously, and a number of NK cell-based therapeutic studies achieved favorable results. Recently, several studies have shown that cytokine supplementation can promote the development and cytotoxicity of NK cells. It has been revealed that direct contact with membrane-bound IL-15 on adjacent stromal cells could induce stronger cytotoxic effects in NK cells in the mice model (140). In a human multicenter phase I study, NKTR-214, a novel IL-2 pathway agonist, showed clinical activity including tumor shrinkage and durable disease stabilization in heavily pretreated patients (141). Moreover, in parallel with $\mathrm{CD}^{+} \mathrm{T}$ cells, NK cells can also be suppressed by immune checkpoint molecules. NKG2D, an essential receptor for the activation of NK cells, has been reported to be upregulated by many ligands in tumor cells (142). Andrade et al. designed antibodies targeting the MICA $\alpha 3$ domain and found that these antibodies prevented human cancer cells from loss of cell surface MICA and MICB (NKG2D ligands). In addition, these antibodies inhibited tumor growth in multiple fully immunocompetent mouse models and reduced human melanoma metastases in a humanized mouse model (143). Monalizumab, a clinically used antibody targeting NKG2A, has been developed to promote NK cell function and has shown the potential to enhance the efficacy of anti-PD-1 therapy in MSS metastatic CRC (144). In addition, other antibodies designed specifically for NK cells, such as lirilumab, are also under clinical trials. Overall, a number of studies have elucidated the possible mechanisms of NK cells, paving the way for clinical research into NK cell-based cancer therapies, and lighting up hope for patients currently resistant to $\mathrm{T}$ cellbased immunotherapy.

\section{B Cell-Based Cancer Immunotherapy}

In addition to $\mathrm{T}$ and $\mathrm{NK}$ cells, the development of $\mathrm{B}$ cell-based immunotherapy strategies may be effective. By bulk and single-cell RNA sequencing, Helmink et al. observed significantly higher levels of B-cell-related gene (such as MZB1, JCHAIN and IGLL5) expression, increased BCR diversity, and clonal expansion in tumor samples from melanoma patients who responded to ICB treatment than patients who did not (145). Besides, a study of gene expression profiles of 608 different subtypes of soft tissue sarcomas found that B cells are the strongest prognostic factor even in the context of high or low $\mathrm{CD}^{+} \mathrm{T}$ cells and cytotoxic contents (146). Considering the relationship between $\mathrm{B}$ cells and patient prognosis, enhancing anti-tumor B cell activity or may have an anti-tumor effect. It has been established that TIL B cells support antitumor immunity and promote immunotherapy responses by acting as APCs, producing high-affinity antibodies and secreting antitumor cytokines. Katoh et al. identified sulfated glycosaminoglycans as the main functional B cell antigen and its natural antibodies showed 
robust growth-suppressive functions against a wide variety of human malignancies (147). Intra-tumoral injection of IL-12 was also shown to activate B cells, leading to good outcomes in HNSCC patients (148). Interestingly, $\mathrm{Lu}$ et al. found a subpopulation of B cells, $\mathrm{ICOSL}^{+} \mathrm{B}$ cells, in breast cancer patients who received neoadjuvant chemotherapy. Moreover, using B-cell specific deletion mice, $\mathrm{ICOSL}^{+} \mathrm{B}$ cells were found to enhance anti-tumor immunity by enhancing effects that modulate $\mathrm{T}$ cell proportions (149). Over the past decade, a population of suppressor B cells, regulatory $B\left(B_{\text {reg }}\right)$ cells, have been shown to play a pivotal role in regulating immune responses involved in cancer. Schioppa et al. identified a population of splenic IL-10 producing $B_{\text {reg }}$ cells implicated in the suppression of $\mathrm{CD}^{+} \mathrm{T}$ cells, which promoted papilloma development and cancer growth in a mouse model of induced skin carcinogenesis (150). The presence of tumor-induced $\mathrm{B}_{\text {reg }}$ cells has also been reported. In a variety of tumor types, IL-21 induced Granzyme B-Expressing $B_{\text {reg }}$ cells has been found to modulate cellular adaptive immune responses by promoting tumor avoidance mechanisms against anti-tumor immune attack (151). On the other hand, in PDAC mice models with KRASmutations, IL35-producing B cells have been reported to play a protumorigenic role, which could be inhibited by CD20 specific monoclonal antibody (152). In advanced CRC, Rituximab, a humanized monoclonal antibody targeting human CD20, apparently reduced the tumor burden (153). All of the above evidence points to the potential of B cell immunotherapy. In the future, new immunotherapy strategies should focus on activating TIL B cells, and how to exploit plasma B cells to promote lymphocyte infiltration and stimulate cytotoxic $\mathrm{T}$ cell activation to increase the antitumor immune response.

\section{CONCLUSION}

In recent years, significant achievements have been witnessed in the field of CRC immunotherapy. $\mathrm{CD}^{+}$TILs are essential for an effective anti-tumor immune response. Monoclonal antibodies that block immune checkpoints to prevent $\mathrm{T}$ cell exhaustion and promote tumor destruction by cytotoxic $\mathrm{CD} 8^{+} \mathrm{T}$ cells, have been shown to be effective in mCRC patients with dMMR-MSI-H. In 2017, pembrolizumab was approved by the FDA for the treatment of all dMMR-MSI-H metastatic solid tumors, becoming the first biomarker-based cancer treatment regimen. However, not all dMMR-MSI-H CRC cases respond to ICIs. Compared with dMMR-MSI-H, pMMR-MSI-L/MSS, which accounts for the majority of CRC with a lower mutation load,

\section{REFERENCES}

1. Jemal A, Bray F, Center MM, Ferlay J, Ward E, Forman D. Global Cancer Statistics. CA Cancer J Clin (2011) 61(2):69-90. doi: 10.3322/caac.20107

2. Dekker E, Tanis PJ, Vleugels JLA, Kasi PM, Wallace MB. Colorectal Cancer. Lancet (2019) 394(10207):1467-80. doi: 10.1016/S0140-6736(19)32319-0

3. Guren MG. The Global Challenge of Colorectal Cancer. Lancet Gastroenterol Hepatol (2019) 4(12):894-5. doi: 10.1016/S2468-1253(19) 30329-2 also shows an unsatisfactory response to ICIs. In tumors without active immune responses, active induction of immune responses by other immunotherapy methods may be required to achieve tumor control in the vast majority of patients with pMMR-MSIL/MSS.

Increasing evidence supports the major role of infiltrating immune cells, especially TILs, in tumor control. In addition to $\mathrm{CD}^{+} \mathrm{T}$ cells, other TILs also have shown the potential in immunotherapy. $\mathrm{CD}^{+} \mathrm{T}$ cells play a key role in enhancing tumor control, both during effector $\mathrm{T}$ cell initiation and in the tumor microenvironment. Vaccines designed to induce a CD4 response have shown significant promise in improving clinical outcomes in subgroups of patients with melanoma and breast cancer (154). While several early trials have yielded promising data, further studies are needed to verify its safety and effectiveness. Moreover, a growing number of studies have the potential to improve our understanding of NK and $\mathrm{B}$ cells antitumor functions, promising positive research in related fields. With insights gained from trials based on NK and B cells, novel therapeutic strategies will likely help to guide clinicians towards a more personalized treatment for CRC patients.

In conclusion, tumor-infiltrating lymphocytes play a significant role in the tumor immune environment. As the regulatory role of TILs in CRC continues to be elucidated, we anticipate that personalized immunotherapy for CRC patients will be realized, and these advances will further drive the clinical success of immunotherapy.

\section{AUTHOR CONTRIBUTIONS}

FW and ZB conceptualized the study. FW oversaw the literature review was involved in all aspects of designing and writing the manuscript. $\mathrm{ZB}$ and $\mathrm{YZ}$ performed the literature review. $\mathrm{ZB}$ wrote the manuscript and designed the figures. JX and ZY provided input on the discussion of various sections. All authors contributed to the article and approved the submitted version.

\section{FUNDING}

This work was supported by the National Natural Science Foundation of China grants 31770827 and 21736002. 
7. Rosenberg SA. Il-2: The First Effective Immunotherapy for Human Cancer. J Immunol (2014) 192(12):5451-8. doi: 10.4049/jimmunol.1490019

8. Hodi FS, O'Day SJ, McDermott DF, Weber RW, Sosman JA, Haanen JB, et al. Improved Survival With Ipilimumab in Patients With Metastatic Melanoma. N Engl J Med (2010) 363(8):711-23. doi: 10.1056/ NEJMoa1003466

9. Borghaei H, Paz-Ares L, Horn L, Spigel DR, Steins M, Ready NE, et al. Nivolumab Versus Docetaxel in Advanced Nonsquamous Non-Small-Cell Lung Cancer. N Engl J Med (2015) 373(17):1627-39. doi: 10.1056/ NEJMoa 1507643

10. Rosenberg JE, Hoffman-Censits J, Powles T, van der Heijden MS, Balar AV, Necchi A, et al. Atezolizumab in Patients With Locally Advanced and Metastatic Urothelial Carcinoma Who Have Progressed Following Treatment With Platinum-Based Chemotherapy: A Single-Arm, Multicentre, Phase 2 Trial. Lancet (2016) 387(10031):1909-20. doi: 10.1016/S0140-6736(16)00561-4

11. Iwai $Y$, Ishida $M$, Tanaka $Y$, Okazaki T, Honjo T, Minato N. Involvement of Pd-L1 on Tumor Cells in the Escape From Host Immune System and Tumor Immunotherapy by Pd-L1 Blockade. Proc Natl Acad Sci USA (2002) 99 (19):12293-7. doi: 10.1073/pnas.192461099

12. Leach DR, Krummel MF, Allison JP. Enhancement of Antitumor Immunity by Ctla-4 Blockade. Science (1996) 271(5256):1734-6. doi: 10.1126/ science.271.5256.1734

13. Cancer Genome Atlas N. Comprehensive Molecular Characterization of Human Colon and Rectal Cancer. Nature (2012) 487(7407):330-7. doi: 10.1038/nature11252

14. Le DT, Uram JN, Wang H, Bartlett BR, Kemberling H, Eyring AD, et al. Pd-1 Blockade in Tumors With Mismatch-Repair Deficiency. N Engl J Med (2015) 372(26):2509-20. doi: 10.1056/NEJMoa1500596

15. Zaanan A, Shi Q, Taieb J, Alberts SR, Meyers JP, Smyrk TC, et al. Role of Deficient DNA Mismatch Repair Status in Patients With Stage Iii Colon Cancer Treated With Folfox Adjuvant Chemotherapy: A Pooled Analysis From 2 Randomized Clinical Trials. JAMA Oncol (2018) 4(3):379-83. doi: 10.1001/jamaoncol.2017.2899

16. Lavin Y, Kobayashi S, Leader A, Amir ED, Elefant N, Bigenwald C, et al. Innate Immune Landscape in Early Lung Adenocarcinoma by Paired SingleCell Analyses. Cell (2017) 169(4):750-65.e717. doi: 10.1016/j.cell. 2017.04.014

17. Sadanandam A, Lyssiotis CA, Homicsko K, Collisson EA, Gibb WJ, Wullschleger S, et al. A Colorectal Cancer Classification System That Associates Cellular Phenotype and Responses to Therapy. Nat Med (2013) 19(5):619-25. doi: 10.1038/nm.3175

18. Havel JJ, Chowell D, Chan TA. The Evolving Landscape of Biomarkers for Checkpoint Inhibitor Immunotherapy. Nat Rev Cancer (2019) 19(3):133-50. doi: 10.1038/s41568-019-0116-x

19. Senovilla L, Vacchelli E, Galon J, Adjemian S, Eggermont A, Fridman WH, et al. Trial Watch: Prognostic and Predictive Value of the Immune Infiltrate in Cancer. Oncoimmunology (2012) 1(8):1323-43. doi: 10.4161/onci.22009

20. Jochems $\mathrm{C}$, Schlom J. Tumor-Infiltrating Immune Cells and Prognosis: The Potential Link Between Conventional Cancer Therapy and Immunity. Exp Biol Med (Maywood) (2011) 236(5):567-79. doi: 10.1258/ebm.2011.011007

21. Fridman WH, Pagès F, Sautès-Fridman C, Galon J. The Immune Contexture in Human Tumours: Impact on Clinical Outcome. Nat Rev Cancer (2012) 12 (4):298-306. doi: 10.1038/nrc3245

22. Fridman WH, Galon J, Pagès F, Tartour E, Sautès-Fridman C, Kroemer G. Prognostic and Predictive Impact of Intra- and Peritumoral Immune Infiltrates. Cancer Res (2011) 71(17):5601-5. doi: 10.1158/0008-5472. CAN-11-1316

23. Mlecnik B, Bindea G, Pagès F, Galon J. Tumor Immunosurveillance in Human Cancers. Cancer Metastasis Rev (2011) 30(1):5-12. doi: 10.1007/ s10555-011-9270-7

24. Galon J, Costes A, Sanchez-Cabo F, Kirilovsky A, Mlecnik B, Lagorce-Pagès C, et al. Type, Density, and Location of Immune Cells Within Human Colorectal Tumors Predict Clinical Outcome. Science (2006) 313 (5795):1960-4. doi: 10.1126/science.1129139

25. Fridman WH, Zitvogel L, Sautès-Fridman C, Kroemer G. The Immune Contexture in Cancer Prognosis and Treatment. Nat Rev Clin Oncol (2017) 14(12):717-34. doi: 10.1038/nrclinonc.2017.101
26. Pagès F, Galon J, Dieu-Nosjean MC, Tartour E, Sautès-Fridman C, Fridman WH. Immune Infiltration in Human Tumors: A Prognostic Factor That Should Not Be Ignored. Oncogene (2010) 29(8):1093-102. doi: 10.1038/ onc.2009.416

27. Idos GE, Kwok J, Bonthala N, Kysh L, Gruber SB, Qu C. The Prognostic Implications of Tumor Infiltrating Lymphocytes in Colorectal Cancer: A Systematic Review and Meta-Analysis. Sci Rep (2020) 10(1):3360. doi: 10.1038/s41598-020-60255-4

28. Rozek LS, Schmit SL, Greenson JK, Tomsho LP, Rennert HS, Rennert G, et al. Tumor-Infiltrating Lymphocytes, Crohn's-Like Lymphoid Reaction, and Survival From Colorectal Cancer. J Natl Cancer Inst (2016) 108(8): djw207. doi: 10.1093/jnci/djw027

29. Llosa NJ, Cruise M, Tam A, Wicks EC, Hechenbleikner EM, Taube JM, et al. The Vigorous Immune Microenvironment of Microsatellite Instable Colon Cancer Is Balanced by Multiple Counter-Inhibitory Checkpoints. Cancer Discov (2015) 5(1):43-51. doi: 10.1158/2159-8290.CD-14-0863

30. Dahlin AM, Henriksson ML, Van Guelpen B, Stenling R, Oberg A, Rutegård J, et al. Colorectal Cancer Prognosis Depends on T-Cell Infiltration and Molecular Characteristics of the Tumor. Mod Pathol (2011) 24(5):671-82. doi: 10.1038/modpathol.2010.234

31. Zhang N, Bevan MJ. Cd8(+) T Cells: Foot Soldiers of the Immune System. Immunity (2011) 35(2):161-8. doi: 10.1016/j.immuni.2011.07.010

32. Pagès F, Berger A, Camus M, Sanchez-Cabo F, Costes A, Molidor R, et al. Effector Memory T Cells, Early Metastasis, and Survival in Colorectal Cancer. N Engl J Med (2005) 353(25):2654-66. doi: 10.1056/NEJMoa051424

33. Russell JH, Ley TJ. Lymphocyte-Mediated Cytotoxicity. Annu Rev Immunol (2002) 20:323-70. doi: 10.1146/annurev.immunol.20.100201.131730

34. Golstein P, Griffiths GM. An Early History of T Cell-Mediated Cytotoxicity. Nat Rev Immunol (2018) 18(8):527-35. doi: 10.1038/s41577-018-0009-3

35. Alspach E, Lussier DM, Schreiber RD. Interferon $\gamma$ and Its Important Roles in Promoting and Inhibiting Spontaneous and Therapeutic Cancer Immunity. Cold Spring Harb Perspect Biol (2019) 11(3):a028480. doi: 10.1101/cshperspect.a028480

36. Liu Y, Zhou N, Zhou L, Wang J, Zhou Y, Zhang T, et al. Il-2 Regulates Tumor-Reactive Cd8(+) T Cell Exhaustion by Activating the Aryl Hydrocarbon Receptor. Nat Immunol (2021) 22(3):358-69. doi: 10.1038/ s41590-020-00850-9

37. Bruni D, Angell HK, Galon J. The Immune Contexture and Immunoscore in Cancer Prognosis and Therapeutic Efficacy. Nat Rev Cancer (2020) 20 (11):662-80. doi: 10.1038/s41568-020-0285-7

38. Salama P, Phillips M, Grieu F, Morris M, Zeps N, Joseph D, et al. TumorInfiltrating Foxp $3+\mathrm{T}$ Regulatory Cells Show Strong Prognostic Significance in Colorectal Cancer. J Clin Oncol (2009) 27(2):186-92. doi: 10.1200/ JCO.2008.18.7229

39. Nosho K, Baba Y, Tanaka N, Shima K, Hayashi M, Meyerhardt JA, et al. Tumour-Infiltrating T-Cell Subsets, Molecular Changes in Colorectal Cancer, and Prognosis: Cohort Study and Literature Review. J Pathol (2010) 222(4):350-66. doi: 10.1002/path.2774

40. Mlecnik B, Tosolini M, Kirilovsky A, Berger A, Bindea G, Meatchi T, et al. Histopathologic-Based Prognostic Factors of Colorectal Cancers Are Associated With the State of the Local Immune Reaction. J Clin Oncol (2011) 29(6):610-8. doi: 10.1200/JCO.2010.30.5425

41. Camus M, Tosolini M, Mlecnik B, Pagès F, Kirilovsky A, Berger A, et al. Coordination of Intratumoral Immune Reaction and Human Colorectal Cancer Recurrence. Cancer Res (2009) 69(6):2685-93. doi: 10.1158/00085472.CAN-08-2654

42. Liu SS, Yang YZ, Jiang C, Quan Q, Xie QK, Wang XP, et al. Comparison of Immunological Characteristics Between Paired Mismatch Repair-Proficient and -Deficient Colorectal Cancer Patients. J Transl Med (2018) 16(1):195. doi: 10.1186/s12967-018-1570-z

43. Le Flahec G, Badic B, Guibourg B, Doucet L, Bail JP, Marcorelles P, et al. Mismatch Repair-Deficient Colorectal Cancer: A Model of Immunogenic and Immune Cell-Rich Tumor Despite Nonsignificant Programmed Cell Death Ligand-1 Expression in Tumor Cells. Hum Pathol (2018) 72:135-43. doi: 10.1016/j.humpath.2017.09.019

44. Michael-Robinson JM, Biemer-Hüttmann A, Purdie DM, Walsh MD, Simms LA, Biden KG, et al. Tumour Infiltrating Lymphocytes and Apoptosis Are Independent Features in Colorectal Cancer Stratified 
According to Microsatellite Instability Status. Gut (2001) 48(3):360-6. doi: 10.1136/gut.48.3.360

45. Phillips SM, Banerjea A, Feakins R, Li SR, Bustin SA, Dorudi S. TumourInfiltrating Lymphocytes in Colorectal Cancer With Microsatellite Instability Are Activated and Cytotoxic. Br J Surg (2004) 91(4):469-75. doi: $10.1002 / b j s .4472$

46. Dolcetti R, Viel A, Doglioni C, Russo A, Guidoboni M, Capozzi E, et al. High Prevalence of Activated Intraepithelial Cytotoxic T Lymphocytes and Increased Neoplastic Cell Apoptosis in Colorectal Carcinomas With Microsatellite Instability. Am J Pathol (1999) 154(6):1805-13. doi: 10.1016/S0002-9440(10)65436-3

47. Mlecnik B, Bindea G, Angell HK, Maby P, Angelova M, Tougeron D, et al. Integrative Analyses of Colorectal Cancer Show Immunoscore Is a Stronger Predictor of Patient Survival Than Microsatellite Instability. Immunity (2016) 44(3):698-711. doi: 10.1016/j.immuni.2016.02.025

48. De Smedt L, Lemahieu J, Palmans S, Govaere O, Tousseyn T, Van Cutsem E, et al. Microsatellite Instable Vs Stable Colon Carcinomas: Analysis of Tumour Heterogeneity, Inflammation and Angiogenesis. Br J Cancer (2015) 113(3):500-9. doi: 10.1038/bjc.2015.213

49. Nestarenkaite A, Fadhil W, Rasmusson A, Susanti S, Hadjimichael E, Laurinaviciene A, et al. Immuno-Interface Score to Predict Outcome in Colorectal Cancer Independent of Microsatellite Instability Status. Cancers (Basel) (2020) 12(10):2902. doi: 10.3390/cancers12102902

50. Le Gouvello S, Bastuji-Garin S, Aloulou N, Mansour H, Chaumette MT, Berrehar F, et al. High Prevalence of Foxp3 and Il17 in Mmr-Proficient Colorectal Carcinomas. Gut (2008) 57(6):772-9. doi: 10.1136/gut.2007. 123794

51. Michel S, Benner A, Tariverdian M, Wentzensen N, Hoefler P, Pommerencke T, et al. High Density of Foxp3-Positive T Cells Infiltrating Colorectal Cancers With Microsatellite Instability. Br J Cancer (2008) 99 (11):1867-73. doi: 10.1038/sj.bjc.6604756

52. Tosolini M, Kirilovsky A, Mlecnik B, Fredriksen T, Mauger S, Bindea G, et al. Clinical Impact of Different Classes of Infiltrating T Cytotoxic and Helper Cells (Th1, Th2, Treg, Th17) in Patients With Colorectal Cancer. Cancer Res (2011) 71(4):1263-71. doi: 10.1158/0008-5472.CAN-10-2907

53. Schreck S, Friebel D, Buettner M, Distel L, Grabenbauer G, Young LS, et al. Prognostic Impact of Tumour-Infiltrating Th2 and Regulatory T Cells in Classical Hodgkin Lymphoma. Hematol Oncol (2009) 27(1):31-9. doi: 10.1002/hon.878

54. Yoon NK, Maresh EL, Shen D, Elshimali Y, Apple S, Horvath S, et al. Higher Levels of Gata3 Predict Better Survival in Women With Breast Cancer. Hum Pathol (2010) 41(12):1794-801. doi: 10.1016/j.humpath.2010.06.010

55. Kusuda T, Shigemasa K, Arihiro K, Fujii T, Nagai N, Ohama K. Relative Expression Levels of Th1 and Th2 Cytokine Mrna Are Independent Prognostic Factors in Patients With Ovarian Cancer. Oncol Rep (2005) 13 (6):1153-8. doi: 10.3892/or.13.6.1153

56. De Monte L, Reni M, Tassi E, Clavenna D, Papa I, Recalde H, et al. Intratumor T Helper Type 2 Cell Infiltrate Correlates With CancerAssociated Fibroblast Thymic Stromal Lymphopoietin Production and Reduced Survival in Pancreatic Cancer. J Exp Med (2011) 208(3):469-78. doi: $10.1084 /$ jem.20101876

57. Ubukata H, Motohashi G, Tabuchi T, Nagata H, Konishi S, Tabuchi T. Evaluations of Interferon- $\Gamma /$ Interleukin-4 Ratio and Neutrophil/ Lymphocyte Ratio as Prognostic Indicators in Gastric Cancer Patients. J Surg Oncol (2010) 102(7):742-7. doi: 10.1002/jso.21725

58. Lv L, Pan K, Li XD, She KL, Zhao JJ, Wang W, et al. The Accumulation and Prognosis Value of Tumor Infiltrating Il-17 Producing Cells in Esophageal Squamous Cell Carcinoma. PloS One (2011) 6(3):e18219. doi: 10.1371/ journal.pone.0018219

59. Chen JG, Xia JC, Liang XT, Pan K, Wang W, Lv L, et al. Intratumoral Expression of Il-17 and Its Prognostic Role in Gastric Adenocarcinoma Patients. Int J Biol Sci (2011) 7(1):53-60. doi: 10.7150/ijbs.7.53

60. Kryczek I, Banerjee M, Cheng P, Vatan L, Szeliga W, Wei S, et al. Phenotype, Distribution, Generation, and Functional and Clinical Relevance of Th17 Cells in the Human Tumor Environments. Blood (2009) 114(6):1141-9. doi: 10.1182/blood-2009-03-208249

61. Punt S, Fleuren GJ, Kritikou E, Lubberts E, Trimbos JB, Jordanova ES, et al. Angels and Demons: Th17 Cells Represent a Beneficial Response, While
Neutrophil Il-17 Is Associated With Poor Prognosis in Squamous Cervical Cancer. Oncoimmunology (2015) 4(1):e984539. doi: 10.4161/2162402X. 2014.984539

62. Chen X, Wan J, Liu J, Xie W, Diao X, Xu J, et al. Increased Il-17-Producing Cells Correlate With Poor Survival and Lymphangiogenesis in Nsclc Patients. Lung Cancer (2010) 69(3):348-54. doi: 10.1016/j.lungcan.2009.11.013

63. Zhang JP, Yan J, Xu J, Pang XH, Chen MS, Li L, et al. Increased Intratumoral Il-17-Producing Cells Correlate With Poor Survival in Hepatocellular Carcinoma Patients. J Hepatol (2009) 50(5):980-9. doi: 10.1016/ j.jhep.2008.12.033

64. Zhang YL, Li J, Mo HY, Qiu F, Zheng LM, Qian CN, et al. Different Subsets of Tumor Infiltrating Lymphocytes Correlate With Npc Progression in Different Ways. Mol Cancer (2010) 9:4. doi: 10.1186/1476-4598-9-4

65. Badoual C, Hans S, Rodriguez J, Peyrard S, Klein C, Agueznay Nel H, et al. Prognostic Value of Tumor-Infiltrating Cd4+ T-Cell Subpopulations in Head and Neck Cancers. Clin Cancer Res (2006) 12(2):465-72. doi: 10.1158/1078-0432.CCR-05-1886

66. Winerdal ME, Marits P, Winerdal M, Hasan M, Rosenblatt R, Tolf A, et al. Foxp3 and Survival in Urinary Bladder Cancer. BJU Int (2011) 108 (10):1672-8. doi: 10.1111/j.1464-410X.2010.10020.x

67. Grabenbauer GG, Lahmer G, Distel L, Niedobitek G. Tumor-Infiltrating Cytotoxic T Cells But Not Regulatory T Cells Predict Outcome in Anal Squamous Cell Carcinoma. Clin Cancer Res (2006) 12(11 Pt 1):3355-60. doi: 10.1158/1078-0432.CCR-05-2434

68. Heimberger AB, Abou-Ghazal M, Reina-Ortiz C, Yang DS, Sun W, Qiao W, et al. Incidence and Prognostic Impact of Foxp3+ Regulatory T Cells in Human Gliomas. Clin Cancer Res (2008) 14(16):5166-72. doi: 10.1158/10780432.CCR-08-0320

69. Jacobs JF, Idema AJ, Bol KF, Grotenhuis JA, de Vries IJ, Wesseling P, et al. Prognostic Significance and Mechanism of Treg Infiltration in Human Brain Tumors. J Neuroimmunol (2010) 225(1-2):195-9. doi: 10.1016/ j.jneuroim.2010.05.020

70. Curiel TJ, Coukos G, Zou L, Alvarez X, Cheng P, Mottram P, et al. Specific Recruitment of Regulatory T Cells in Ovarian Carcinoma Fosters Immune Privilege and Predicts Reduced Survival. Nat Med (2004) 10(9):942-9. doi: 10.1038/nm1093

71. Pasero C, Gravis G, Granjeaud S, Guerin M, Thomassin-Piana J, Rocchi P, et al. Highly Effective Nk Cells Are Associated With Good Prognosis in Patients With Metastatic Prostate Cancer. Oncotarget (2015) 6(16):1436073. doi: 10.18632 /oncotarget. 3965

72. Coca S, Perez-Piqueras J, Martinez D, Colmenarejo A, Saez MA, Vallejo C, et al. The Prognostic Significance of Intratumoral Natural Killer Cells in Patients With Colorectal Carcinoma. Cancer (1997) 79(12):2320-8. doi: 10.1002/(SICI) 1097-0142(19970615)79:12<2320::AID-CNCR5>3.0.CO;2-P

73. Okada K, Sadahiro S, Chan LF, Ogimi T, Miyakita H, Saito G, et al. The Number of Natural Killer Cells in the Largest Diameter Lymph Nodes Is Associated With the Number of Retrieved Lymph Nodes and Lymph Node Size, and Is an Independent Prognostic Factor in Patients With Stage II Colon Cancer. Oncology (2018) 95(5):288-96. doi: 10.1159/000491019

74. Tang YP, Xie MZ, Li KZ, Li JL, Cai ZM, Hu BL. Prognostic Value of Peripheral Blood Natural Killer Cells in Colorectal Cancer. BMC Gastroenterol (2020) 20(1):31. doi: 10.1186/s12876-020-1177-8

75. Menon AG, Janssen-van Rhijn CM, Morreau H, Putter H, Tollenaar RA, van de Velde CJ, et al. Immune System and Prognosis in Colorectal Cancer: A Detailed Immunohistochemical Analysis. Lab Invest (2004) 84(4):493-501. doi: 10.1038/labinvest. 3700055

76. Melero I, Rouzaut A, Motz GT, Coukos G. T-Cell and Nk-Cell Infiltration Into Solid Tumors: A Key Limiting Factor for Efficacious Cancer Immunotherapy. Cancer Discov (2014) 4(5):522-6. doi: 10.1158/21598290.CD-13-0985

77. Rathore AS, Goel MM, Makker A, Kumar S, Srivastava AN. Is the Tumor Infiltrating Natural Killer Cell (Nk-Tils) Count in Infiltrating Ductal Carcinoma of Breast Prognostically Significant? Asian Pac J Cancer Prev (2014) 15(8):3757-61. doi: 10.7314/APJCP.2014.15.8.3757

78. Liu Y, Cheng Y, Xu Y, Wang Z, Du X, Li C, et al. Increased Expression of Programmed Cell Death Protein 1 on Nk Cells Inhibits Nk-Cell-Mediated Anti-Tumor Function and Indicates Poor Prognosis in Digestive Cancers. Oncogene (2017) 36(44):6143-53. doi: 10.1038/onc.2017.209 
79. Wada Y, Nakashima O, Kutami R, Yamamoto O, Kojiro M. Clinicopathological Study on Hepatocellular Carcinoma With Lymphocytic Infiltration. Hepatology (1998) 27(2):407-14. doi: 10.1002/hep.510270214

80. Ladányi A, Kiss J, Mohos A, Somlai B, Liszkay G, Gilde K, et al. Prognostic Impact of B-Cell Density in Cutaneous Melanoma. Cancer Immunol Immunother (2011) 60(12):1729-38. doi: 10.1007/s00262-011-1071-x

81. Nielsen JS, Sahota RA, Milne K, Kost SE, Nesslinger NJ, Watson PH, et al. Cd20+ Tumor-Infiltrating Lymphocytes Have an Atypical Cd27- Memory Phenotype and Together With Cd8+ T Cells Promote Favorable Prognosis in Ovarian Cancer. Clin Cancer Res (2012) 18(12):3281-92. doi: 10.1158/ 1078-0432.CCR-12-0234

82. Al-Shibli KI, Donnem T, Al-Saad S, Persson M, Bremnes RM, Busund LT. Prognostic Effect of Epithelial and Stromal Lymphocyte Infiltration in NonSmall Cell Lung Cancer. Clin Cancer Res (2008) 14(16):5220-7. doi: 10.1158/ 1078-0432.CCR-08-0133

83. Nedergaard BS, Ladekarl M, Nyengaard JR, Nielsen K. A Comparative Study of the Cellular Immune Response in Patients With Stage Ib Cervical Squamous Cell Carcinoma. Low Numbers of Several Immune Cell Subtypes Are Strongly Associated With Relapse of Disease Within 5 Years. Gynecol Oncol (2008) 108(1):106-11. doi: 10.1016/j.ygyno.2007.08.089

84. Yang C, Lee H, Pal S, Jove V, Deng J, Zhang W, et al. B Cells Promote Tumor Progression Via Stat3 Regulated-Angiogenesis. PloS One (2013) 8(5):e64159. doi: 10.1371/journal.pone.0064159

85. Shen $M$, Wang J, Ren X. New Insights Into Tumor-Infiltrating $B$ Lymphocytes in Breast Cancer: Clinical Impacts and Regulatory Mechanisms. Front Immunol (2018) 9:470. doi: 10.3389/fimmu.2018.00470

86. Tassi E, Gavazzi F, Albarello L, Senyukov V, Longhi R, Dellabona P, et al. Carcinoembryonic Antigen-Specific But Not Antiviral Cd4+ T Cell Immunity Is Impaired in Pancreatic Carcinoma Patients. J Immunol (2008) 181(9):6595-603. doi: 10.4049/jimmunol.181.9.6595

87. Guéry L, Hugues S. Th17 Cell Plasticity and Functions in Cancer Immunity. BioMed Res Int (2015) 2015:314620. doi: 10.1155/2015/314620

88. Bindea G, Mlecnik B, Tosolini M, Kirilovsky A, Waldner M, Obenauf AC, et al. Spatiotemporal Dynamics of Intratumoral Immune Cells Reveal the Immune Landscape in Human Cancer. Immunity (2013) 39(4):782-95. doi: 10.1016/j.immuni.2013.10.003

89. Zhang L, Yu X, Zheng L, Zhang Y, Li Y, Fang Q, et al. Lineage Tracking Reveals Dynamic Relationships of $\mathrm{T}$ Cells in Colorectal Cancer. Nature (2018) 564(7735):268-72. doi: 10.1038/s41586-018-0694-X

90. Schmetterer KG, Neunkirchner A, Pickl WF. Naturally Occurring Regulatory T Cells: Markers, Mechanisms, and Manipulation. FASEB J (2012) 26(6):2253-76. doi: 10.1096/fj.11-193672

91. Frey DM, Droeser RA, Viehl CT, Zlobec I, Lugli A, Zingg U, et al. High Frequency of Tumor-Infiltrating Foxp3(+) Regulatory T Cells Predicts Improved Survival in Mismatch Repair-Proficient Colorectal Cancer Patients. Int J Cancer (2010) 126(11):2635-43. doi: 10.1002/ijc.24989

92. Gunnarsson U, Strigård K, Edin S, Gkekas I, Mustonen H, Kaprio T, et al. Association Between Local Immune Cell Infiltration, Mismatch Repair Status and Systemic Inflammatory Response in Colorectal Cancer. J Transl Med (2020) 18(1):178. doi: 10.1186/s12967-020-02336-6

93. Sun JC, Lanier LL. Nk Cell Development, Homeostasis and Function: Parallels With Cd8 ${ }^{+}$T Cells. Nat Rev Immunol (2011) 11(10):645-57. doi: $10.1038 /$ nri3044

94. Mandal A, Viswanathan C. Natural Killer Cells: In Health and Disease. Hematol Oncol Stem Cell Ther (2015) 8(2):47-55. doi: 10.1016/ j.hemonc.2014.11.006

95. Vivier E, Raulet DH, Moretta A, Caligiuri MA, Zitvogel L, Lanier LL, et al. Innate or Adaptive Immunity? The Example of Natural Killer Cells. Science (2011) 331(6013):44-9. doi: 10.1126/science.1198687

96. Marrack P, Kappler J. Control of T Cell Viability. Annu Rev Immunol (2004) 22:765-87. doi: 10.1146/annurev.immunol.22.012703.104554

97. Cui G, Staron MM, Gray SM, Ho PC, Amezquita RA, Wu J, et al. Il-7Induced Glycerol Transport and Tag Synthesis Promotes Memory Cd8+ T Cell Longevity. Cell (2015) 161(4):750-61. doi: 10.1016/j.cell.2015.03.021

98. Clénet ML, Gagnon F, Moratalla AC, Viel EC, Arbour N. Peripheral Human Cd4(+)Cd8(+) T Lymphocytes Exhibit a Memory Phenotype and Enhanced Responses to Il-2, Il-7 and Il-15. Sci Rep (2017) 7(1):11612. doi: 10.1038/ s41598-017-11926-2
99. Luetke-Eversloh M, Cicek BB, Siracusa F, Thom JT, Hamann A, Frischbutter $S$, et al. Nk Cells Gain Higher Ifn- $\Gamma$ Competence During Terminal Differentiation. Eur J Immunol (2014) 44(7):2074-84. doi: 10.1002/ eji.201344072

100. Vivier E, Ugolini S, Blaise D, Chabannon C, Brossay L. Targeting Natural Killer Cells and Natural Killer T Cells in Cancer. Nat Rev Immunol (2012) 12 (4):239-52. doi: 10.1038/nri3174

101. Sun JC, Beilke JN, Lanier LL. Adaptive Immune Features of Natural Killer Cells. Nature (2009) 457(7229):557-61. doi: 10.1038/nature07665

102. Cichocki F, Grzywacz B, Miller JS. Human Nk Cell Development: One Road or Many? Front Immunol (2019) 10:2078. doi: 10.3389/fimmu.2019.02078

103. Wagner JA, Rosario M, Romee R, Berrien-Elliott MM, Schneider SE, Leong JW, et al. Cd56bright Nk Cells Exhibit Potent Antitumor Responses Following Il-15 Priming. J Clin Invest (2017) 127(11):4042-58. doi: 10.1172/JCI90387

104. Cooper MA, Fehniger TA, Caligiuri MA. The Biology of Human Natural Killer-Cell Subsets. Trends Immunol (2001) 22(11):633-40. doi: 10.1016/ S1471-4906(01)02060-9

105. Cooper MA, Fehniger TA, Turner SC, Chen KS, Ghaheri BA, Ghayur T, et al. Human Natural Killer Cells: A Unique Innate Immunoregulatory Role for the Cd56(Bright) Subset. Blood (2001) 97(10):3146-51. doi: 10.1182/ blood.V97.10.3146

106. Marquardt N, Kekäläinen E, Chen P, Kvedaraite E, Wilson JN, Ivarsson MA, et al. Human Lung Natural Killer Cells Are Predominantly Comprised of Highly Differentiated Hypofunctional Cd69(-)Cd56(Dim) Cells. J Allergy Clin Immunol (2017) 139(4):1321-30.e1324. doi: 10.1016/j.jaci.2016.07.043

107. Marquardt N, Béziat V, Nyström S, Hengst J, Ivarsson MA, Kekäläinen E, et al. Cutting Edge: Identification and Characterization of Human Intrahepatic Cd49a+ Nk Cells. J Immunol (2015) 194(6):2467-71. doi: 10.4049/jimmunol.1402756

108. Boulenouar S, Michelet X, Duquette D, Alvarez D, Hogan AE, Dold C, et al. Adipose Type One Innate Lymphoid Cells Regulate Macrophage Homeostasis Through Targeted Cytotoxicity. Immunity (2017) 46(2):27386. doi: 10.1016/j.immuni.2017.01.008

109. Simoni Y, Fehlings M, Kløverpris HN, McGovern N, Koo SL, Loh CY, et al. Human Innate Lymphoid Cell Subsets Possess Tissue-Type Based Heterogeneity in Phenotype and Frequency. Immunity (2017) 46(1):14861. doi: 10.1016/j.immuni.2016.11.005

110. Picard E, Godet Y, Laheurte C, Dosset M, Galaine J, Beziaud L, et al. Circulating Nkp46(+) Natural Killer Cells Have a Potential Regulatory Property and Predict Distinct Survival in Non-Small Cell Lung Cancer. Oncoimmunology (2019) 8(2):e1527498. doi: 10.1080/2162402X.2018.1527498

111. Zhou XH, Zhang XY, Liang JH, Zhu HY, Wang L, Xia Y, et al. Low Absolute Nk Cell Counts in Peripheral Blood Are Associated With Inferior Survival in Patients With Mantle Cell Lymphoma. Cancer biomark (2019) 24(4):439-47. doi: 10.3233/CBM-182193

112. Fend L, Rusakiewicz S, Adam J, Bastien B, Caignard A, Messaoudene M, et al. Prognostic Impact of the Expression of Ncrl and Ncr3 Nk Cell Receptors and Pd-L1 on Advanced Non-Small Cell Lung Cancer. Oncoimmunology (2017) 6 (1):e1163456. doi: 10.1080/2162402X.2016.1163456

113. Edin S, Kaprio T, Hagström J, Larsson P, Mustonen H, Böckelman C, et al. The Prognostic Importance of Cd20(+) B Lymphocytes in Colorectal Cancer and the Relation to Other Immune Cell Subsets. Sci Rep (2019) 9(1):19997. doi: 10.1038/s41598-019-56441-8

114. Wang SS, Liu W, Ly D, Xu H, Qu L, Zhang L. Tumor-Infiltrating B Cells: Their Role and Application in Anti-Tumor Immunity in Lung Cancer. Cell Mol Immunol (2019) 16(1):6-18. doi: 10.1038/s41423-018-0027-x

115. Kobayashi S, Watanabe T, Suzuki R, Furu M, Ito H, Ito J, et al. Tgf- $\beta$ Induces the Differentiation of Human Cxcl13-Producing Cd4(+) T Cells. Eur J Immunol (2016) 46(2):360-71. doi: 10.1002/eji.201546043

116. Galon J, Angell HK, Bedognetti D, Marincola FM. The Continuum of Cancer Immunosurveillance: Prognostic, Predictive, and Mechanistic Signatures. Immunity (2013) 39(1):11-26. doi: 10.1016/j.immuni.2013.07.008

117. Pitzalis C, Jones GW, Bombardieri M, Jones SA. Ectopic Lymphoid-Like Structures in Infection, Cancer and Autoimmunity. Nat Rev Immunol (2014) 14(7):447-62. doi: 10.1038/nri3700

118. Germain C, Gnjatic S, Tamzalit F, Knockaert S, Remark R, Goc J, et al. Presence of B Cells in Tertiary Lymphoid Structures Is Associated With a 
Protective Immunity in Patients With Lung Cancer. Am J Respir Crit Care Med (2014) 189(7):832-44. doi: 10.1164/rccm.201309-1611OC

119. Kroeger DR, Milne K, Nelson BH. Tumor-Infiltrating Plasma Cells Are Associated With Tertiary Lymphoid Structures, Cytolytic T-Cell Responses, and Superior Prognosis in Ovarian Cancer. Clin Cancer Res (2016) 22 (12):3005-15. doi: 10.1158/1078-0432.CCR-15-2762

120. Dieu-Nosjean MC, Antoine M, Danel C, Heudes D, Wislez M, Poulot V, et al. Long-Term Survival for Patients With Non-Small-Cell Lung Cancer With Intratumoral Lymphoid Structures. J Clin Oncol (2008) 26(27):4410-7. doi: 10.1200/JCO.2007.15.0284

121. Liu X, Tsang JYS, Hlaing T, Hu J, Ni YB, Chan SK, et al. Distinct Tertiary Lymphoid Structure Associations and Their Prognostic Relevance in Her2 Positive and Negative Breast Cancers. Oncologist (2017) 22(11):1316-24. doi: 10.1634/theoncologist.2017-0029

122. Cabrita R, Lauss M, Sanna A, Donia M, Skaarup Larsen M, Mitra S, et al. Tertiary Lymphoid Structures Improve Immunotherapy and Survival in Melanoma. Nature (2020) 577(7791):561-5. doi: 10.1038/s41586-019-1914-8

123. Finkin S, Yuan D, Stein I, Taniguchi K, Weber A, Unger K, et al. Ectopic Lymphoid Structures Function as Microniches for Tumor Progenitor Cells in Hepatocellular Carcinoma. Nat Immunol (2015) 16(12):1235-44. doi: 10.1038/ni.3290

124. Ogino S, Nosho K, Irahara N, Meyerhardt JA, Baba Y, Shima K, et al. Lymphocytic Reaction to Colorectal Cancer Is Associated With Longer Survival, Independent of Lymph Node Count, Microsatellite Instability, and Cpg Island Methylator Phenotype. Clin Cancer Res (2009) 15 (20):6412-20. doi: 10.1158/1078-0432.CCR-09-1438

125. Meshcheryakova A, Tamandl D, Bajna E, Stift J, Mittlboeck M, Svoboda M, et al. B Cells and Ectopic Follicular Structures: Novel Players in Anti-Tumor Programming With Prognostic Power for Patients With Metastatic Colorectal Cancer. PloS One (2014) 9(6):e99008. doi: 10.1371/journal. pone. 0099008

126. Di Caro G, Bergomas F, Grizzi F, Doni A, Bianchi P, Malesci A, et al. Occurrence of Tertiary Lymphoid Tissue Is Associated With T-Cell Infiltration and Predicts Better Prognosis in Early-Stage Colorectal Cancers. Clin Cancer Res (2014) 20(8):2147-58. doi: 10.1158/10780432.CCR-13-2590

127. Posch F, Silina K, Leibl S, Mündlein A, Moch H, Siebenhüner A, et al. Maturation of Tertiary Lymphoid Structures and Recurrence of Stage Ii and Iii Colorectal Cancer. Oncoimmunology (2018) 7(2):e1378844. doi: 10.1080/ 2162402X.2017.1378844

128. Yamaguchi K, Ito M, Ohmura H, Hanamura F, Nakano M, Tsuchihashi K, et al. Helper T Cell-Dominant Tertiary Lymphoid Structures Are Associated With Disease Relapse of Advanced Colorectal Cancer. Oncoimmunology (2020) 9(1):1724763. doi: 10.1080/2162402X.2020.1724763

129. Wei SC, Duffy CR, Allison JP. Fundamental Mechanisms of Immune Checkpoint Blockade Therapy. Cancer Discov (2018) 8(9):1069-86. doi: 10.1158/2159-8290.CD-18-0367

130. Chung KY, Gore I, Fong L, Venook A, Beck SB, Dorazio P, et al. Phase Ii Study of the Anti-Cytotoxic T-Lymphocyte-Associated Antigen 4 Monoclonal Antibody, Tremelimumab, in Patients With Refractory Metastatic Colorectal Cancer. J Clin Oncol (2010) 28(21):3485-90. doi: 10.1200/JCO.2010.28.3994

131. Brahmer JR, Tykodi SS, Chow LQ, Hwu WJ, Topalian SL, Hwu P, et al. Safety and Activity of Anti-Pd-L1 Antibody in Patients With Advanced Cancer. N Engl J Med (2012) 366(26):2455-65. doi: 10.1056/NEJMoa1200694

132. Le DT, Uram JN, Wang H, Bartlett B, Kemberling H, Eyring A, et al. Programmed Death-1 Blockade in Mismatch Repair Deficient Colorectal Cancer. J Clin Oncol (2016) 34(15_suppl):103-3. doi: 10.1200/ JCO.2016.34.15_suppl.103

133. Lemery S, Keegan P, Pazdur R. First Fda Approval Agnostic of Cancer Site When a Biomarker Defines the Indication. N Engl J Med (2017) 377 (15):1409-12. doi: 10.1056/NEJMp1709968

134. Overman MJ, McDermott R, Leach JL, Lonardi S, Lenz HJ, Morse MA, et al. Nivolumab in Patients With Metastatic DNA Mismatch Repair-Deficient or Microsatellite Instability-High Colorectal Cancer (Checkmate 142): An Open-Label, Multicentre, Phase 2 Study. Lancet Oncol (2017) 18(9):118291. doi: 10.1016/S1470-2045(17)30422-9
135. Prendergast GC, Smith C, Thomas S, Mandik-Nayak L, Laury-Kleintop L, Metz R, et al. Indoleamine 2,3-Dioxygenase Pathways of Pathogenic Inflammation and Immune Escape in Cancer. Cancer Immunol Immunother (2014) 63(7):721-35. doi: 10.1007/s00262-014-1549-4

136. Kitsou M, Ayiomamitis GD, Zaravinos A. High Expression of Immune Checkpoints Is Associated With the Til Load, Mutation Rate and Patient Survival in Colorectal Cancer. Int J Oncol (2020) 57(1):237-48. doi: 10.3892/ ijo.2020.5062

137. Pflugler S, Svinka J, Scharf I, Crncec I, Filipits M, Charoentong P, et al. Ido1 (+) Paneth Cells Promote Immune Escape of Colorectal Cancer. Commun Biol (2020) 3(1):252. doi: 10.1038/s42003-020-0989-y

138. Lee MH, Yanagawa J, Tran L, Walser TC, Bisht B, Fung E, et al. Fra1 Contributes to Mek-Erk Pathway-Dependent Pd-L1 Upregulation by Kras Mutation in Premalignant Human Bronchial Epithelial Cells. Am J Transl Res (2020) 12(2):409-27.

139. Bendell JC, Kim TW, Goh BC, Wallin J, Oh DY, Han SW, et al. Clinical Activity and Safety of Cobimetinib (Cobi) and Atezolizumab in Colorectal Cancer (Crc). Am Soc of Clin Oncol (2016) 3502. doi: 10.1200/ JCO.2016.34.15_suppl.3502

140. Kobayashi H, Dubois S, Sato N, Sabzevari H, Sakai Y, Waldmann TA, et al. Role of Trans-Cellular Il-15 Presentation in the Activation of Nk CellMediated Killing, Which Leads to Enhanced Tumor Immunosurveillance. Blood (2005) 105(2):721-7. doi: 10.1182/blood-2003-12-4187

141. Bentebibel SE, Hurwitz ME, Bernatchez C, Haymaker C, Hudgens CW, Kluger HM, et al. A First-In-Human Study and Biomarker Analysis of Nktr214, a Novel Il2r $\beta \gamma$-Biased Cytokine, in Patients With Advanced or Metastatic Solid Tumors. Cancer Discov (2019) 9(6):711-21. doi: 10.1158/ 2159-8290.CD-18-1495

142. Takaki R, Hayakawa Y, Nelson A, Sivakumar PV, Hughes S, Smyth MJ, et al. Il-21 Enhances Tumor Rejection Through a Nkg2d-Dependent Mechanism. J Immunol (2005) 175(4):2167-73. doi: 10.4049/jimmunol.175.4.2167

143. Ferrari de Andrade L, Tay RE, Pan D, Luoma AM, Ito Y, Badrinath S, et al. Antibody-Mediated Inhibition of Mica and Micb Shedding Promotes Nk Cell-Driven Tumor Immunity. Science (2018) 359(6383):1537-42. doi: 10.1126/science.aao0505

144. Segal NH, Naidoo J, Curigliano G, Patel S, Sahebjam S, Papadopoulos KP, et al. First-In-Human Dose Escalation of Monalizumab Plus Durvalumab, With Expansion in Patients With Metastatic Microsatellite-Stable Colorectal Cancer. J Clin Oncol (2018) 36(15_suppl):3540-0. doi: 10.1200/ JCO.2018.36.15_suppl.3540

145. Helmink BA, Reddy SM, Gao J, Zhang S, Basar R, Thakur R, et al. B Cells and Tertiary Lymphoid Structures Promote Immunotherapy Response. Nature (2020) 577(7791):549-55. doi: 10.1038/s41586-019-1922-8

146. Petitprez F, de Reyniès A, Keung EZ, Chen TW, Sun CM, Calderaro J, et al. B Cells Are Associated With Survival and Immunotherapy Response in Sarcoma. Nature (2020) 577(7791):556-60. doi: 10.1038/s41586-019-1906-8

147. Katoh H, Komura D, Konishi H, Suzuki R, Yamamoto A, Kakiuchi M, et al. Immunogenetic Profiling for Gastric Cancers Identifies Sulfated Glycosaminoglycans as Major and Functional B Cell Antigens in Human Malignancies. Cell Rep (2017) 20(5):1073-87. doi: 10.1016/j.celrep.2017.07.016

148. van Herpen CM, van der Voort R, van der Laak JA, Klasen IS, de Graaf AO, van Kempen LC, et al. Intratumoral Rhil-12 Administration in Head and Neck Squamous Cell Carcinoma Patients Induces B Cell Activation. Int J Cancer (2008) 123(10):2354-61. doi: 10.1002/ijc.23756

149. Lu Y, Zhao Q, Liao JY, Song E, Xia Q, Pan J, et al. Complement Signals Determine Opposite Effects of B Cells in Chemotherapy-Induced Immunity. Cell (2020) 180(6):1081-97.e1024. doi: 10.1016/j.cell.2020.02.015

150. Schioppa T, Moore R, Thompson RG, Rosser EC, Kulbe H, Nedospasov S, et al. B Regulatory Cells and the Tumor-Promoting Actions of Tnf- $\alpha$ During Squamous Carcinogenesis. Proc Natl Acad Sci USA (2011) 108(26):10662-7. doi: 10.1073/pnas.1100994108

151. Lindner S, Dahlke K, Sontheimer K, Hagn M, Kaltenmeier C, Barth TF, et al. Interleukin 21-Induced Granzyme B-Expressing B Cells Infiltrate Tumors and Regulate T Cells. Cancer Res (2013) 73(8):2468-79. doi: 10.1158/00085472.CAN-12-3450

152. Lee KE, Spata M, Bayne LJ, Buza EL, Durham AC, Allman D, et al. Hifla Deletion Reveals Pro-Neoplastic Function of B Cells in Pancreatic 
Neoplasia. Cancer Discov (2016) 6(3):256-69. doi: 10.1158/2159-8290.CD15-0822

153. Barbera-Guillem E, Nelson MB, Barr B, Nyhus JK, May KF Jr, Feng L, et al. B Lymphocyte Pathology in Human Colorectal Cancer. Experimental and Clinical Therapeutic Effects of Partial B Cell Depletion. Cancer Immunol Immunother (2000) 48(10):541-9. doi: 10.1007/pl00006672

154. Melssen M, Slingluff CLJr. Vaccines Targeting Helper T Cells for Cancer Immunotherapy. Curr Opin Immunol (2017) 47:85-92. doi: 10.1016/j.coi.2017.07.004

Conflict of Interest: The authors declare that the research was conducted in the absence of any commercial or financial relationships that could be construed as a potential conflict of interest.
Publisher's Note: All claims expressed in this article are solely those of the authors and do not necessarily represent those of their affiliated organizations, or those of the publisher, the editors and the reviewers. Any product that may be evaluated in this article, or claim that may be made by its manufacturer, is not guaranteed or endorsed by the publisher.

Copyright $\odot 2022$ Bai, Zhou, Ye, Xiong, Lan and Wang. This is an open-access article distributed under the terms of the Creative Commons Attribution License (CC BY). The use, distribution or reproduction in other forums is permitted, provided the original author(s) and the copyright owner(s) are credited and that the original publication in this journal is cited, in accordance with accepted academic practice. No use, distribution or reproduction is permitted which does not comply with these terms. 